Pacific Northwest National Laboratory

Operated by Battelle for the U.S. Department of Energy

Under Contract DE-AC05-76RL01830

\title{
Facilitation of the Estuary/Ocean Subgroup and the Expert Regional Technical Group, Fiscal Year 2013 Annual Report
}

\author{
Final Report
}

GE Johnson and NK Sather

September 2013

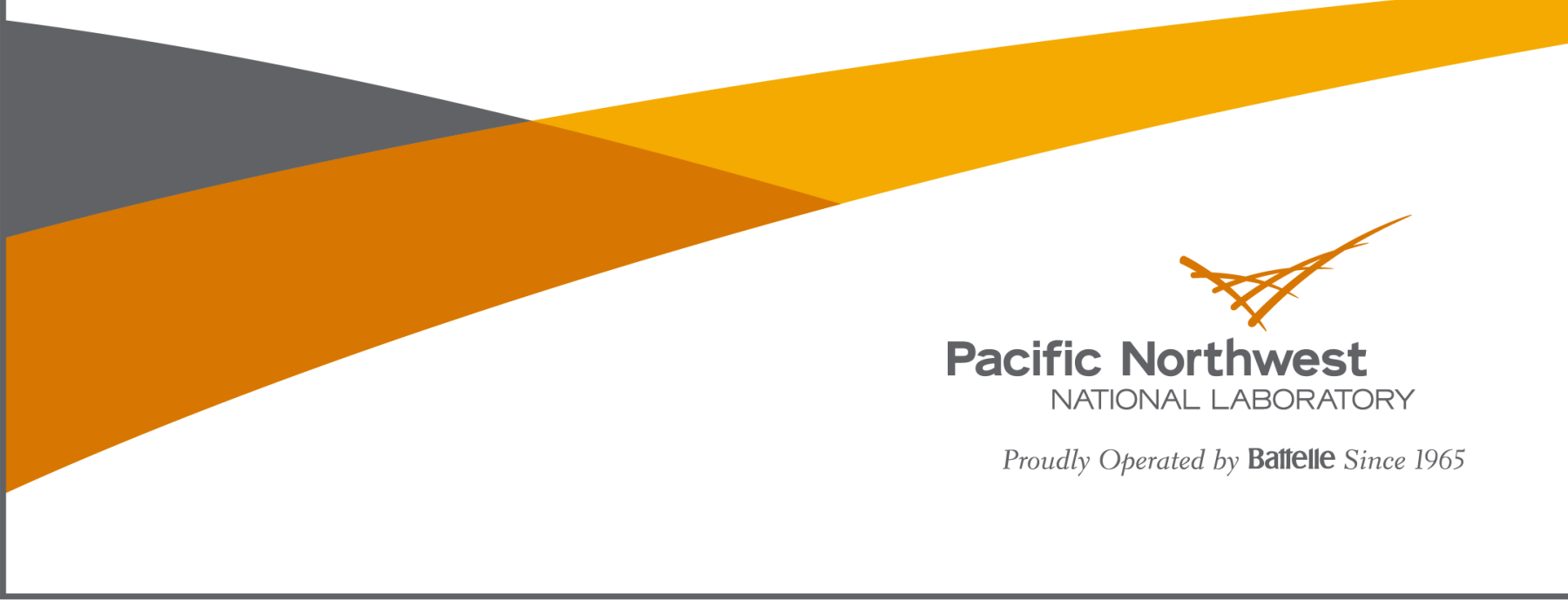




\title{
DISCLAIMER
}

This report was prepared as an account of work sponsored by an agency of the United States Government. Neither the United States Government nor any agency thereof, nor Battelle Memorial Institute, nor any of their employees, makes any warranty, express or implied, or assumes any legal liability or responsibility for the accuracy, completeness, or usefulness of any information, apparatus, product, or process disclosed, or represents that its use would not infringe privately owned rights. Reference herein to any specific commercial product, process, or service by trade name, trademark, manufacturer, or otherwise does not necessarily constitute or imply its endorsement, recommendation, or favoring by the United States Government or any agency thereof, or Battelle Memorial Institute. The views and opinions of authors expressed herein do not necessarily state or reflect those of the United States Government or any agency thereof.

\author{
PACIFIC NORTHWEST NATIONAL LABORATORY \\ operated by \\ BATTELLE \\ for the \\ UNITED STATES DEPARTMENT OF ENERGY \\ under Contract DE-AC05-76RL01830
}

Printed in the United States of America
Available to DOE and DOE contractors from the Office of Scientific and Technical Information,
P.O. Box 62, Oak Ridge, TN 37831-0062;
ph: (865) 576-8401
fax: $(865)$ 576-5728
email: reports@adonis.osti.gov

\begin{abstract}
Available to the public from the National Technical Information Service, U.S. Department of Commerce, 5285 Port Royal Rd., Springfield, VA 22161 ph: (800) 553-6847 fax: $(703) 605-6900$ email: orders@ntis.fedworld.gov online ordering: http://www.ntis.gov/ordering.htm
\end{abstract}

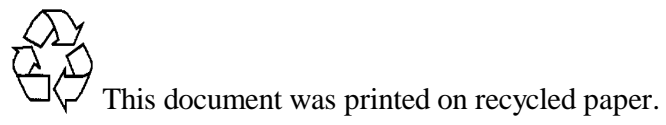




\section{Facilitation of the Estuary/Ocean Subgroup and the Expert Regional Technical Group, Fiscal Year 2013 Annual Report}

Final Report

GE Johnson and NK Sather

September 2013

Prepared for the Bonneville Power Administration under an Agreement with the U.S. Department of Energy Contract DE-AC05-76RLO1830

Pacific Northwest National Laboratory

Richland, Washington 99352 


\section{Preface}

This project covers facilitation of the Estuary/Ocean Subgroup (EOS) for federal research, monitoring, and evaluation (RME) and the Expert Regional Technical Group (ERTG) for estuary habitat restoration. The EOS is part of the research, monitoring, and evaluation effort that the Action Agencies (Bonneville Power Administration [BPA], U.S. Army Corps of Engineers [Corps], U.S. Bureau of Reclamation) developed in response to obligations arising from the Endangered Species Act as applied to operation of the Federal Columbia River Power System (FCRPS). The EOS is tasked by National Marine Fisheries Service (NMFS) and the Action Agencies (AAs) to design and coordinate implementation of the federal RME plan for the lower Columbia River and estuary, including the river's plume in the ocean. Initiated in 2002, the EOS is composed of members from BPA, the Corps, NMFS, and Pacific Northwest National Laboratory's (PNNL's) Marine Sciences Laboratory, and other agencies as necessary.

The ERTG assigns survival benefit units for ocean- and stream-type juvenile salmon from estuary habitat actions implemented by the AAs as called for in the 2008 Biological Opinion (BiOp) of Federal Columbia River Power System Operations. The ERTG comprises members from NMFS, Oregon Department of Fish and Wildlife, PNNL, Skagit River Cooperative, and Washington Department of Fish and Wildlife. The ERTG's Steering Committee includes representatives from BPA, the Corps, and NMFS.

The BPA contracted with PNNL to coordinate and facilitate the EOS and the ERTG (Contract No. 56065 , release 3). This annual report is a fiscal year 2013 deliverable for the project titled Facilitation of the EOS and ERTG (BPA Project No. 2002-077-00 and PNNL Project No. 63359). Ben Zelinsky (503230-4737) was BPA's contracting officer's technical representative for this project. For more information about PNNL's conduct of this project, please contact the project manager, Gary Johnson (503-417-7567). 


\section{Acknowledgments}

Important contributions to the EOS and ERTG during fiscal year 2013 were made by Blaine Ebberts and Cindy Studebaker (Portland District, Corps); Julie Doumbia, Dave Roberts, Russell Scranton, and Ben Zelinsky (BPA); Catherine Corbett (Lower Columbia Estuary Partnership); and Lynne Krasnow (NMFS). Assistance from the following PNNL staff is much appreciated: Susan Ennor, Erin Nave, Jan Slater, and Ron Thom. 



\section{Acronyms and Abbreviations}

\begin{tabular}{|c|c|}
\hline AA & Action Agencies \\
\hline AER & action effectiveness and monitoring research \\
\hline AFEP & Anadromous Fish Evaluation Program \\
\hline $\mathrm{BiOp}$ & Biological Opinion \\
\hline BPA & Bonneville Power Administration \\
\hline CEERP & Columbia Estuary Ecosystem Restoration Program \\
\hline CLT & Columbia Land Trust \\
\hline Corps & U.S. Army Corps of Engineers \\
\hline CREC & Columbia River Estuary Conference \\
\hline CREDDP & Columbia River Estuary Data Development Program \\
\hline CREST & Columbia River Estuary Study Taskforce \\
\hline Council & Northwest Power and Conservation Council \\
\hline EOS & Estuary/Ocean Subgroup \\
\hline EP & Estuary Partnership \\
\hline ERTG & Expert Regional Technical Group \\
\hline FCRPS & Federal Columbia River Power System \\
\hline FY & fiscal year \\
\hline ISRP & Independent Scientific Review Panel \\
\hline LCRE & lower Columbia River and estuary \\
\hline NMFS & National Marine Fisheries Service \\
\hline NOAA & National Oceanic and Atmospheric Administration \\
\hline PNNL & Pacific Northwest National Laboratory \\
\hline RME & research, monitoring, and evaluation \\
\hline RPA & Reasonable and Prudent Alternative \\
\hline SBU & survival benefit unit \\
\hline WE & work element (Pisces) \\
\hline
\end{tabular}





\section{Contents}

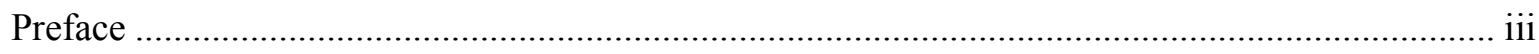

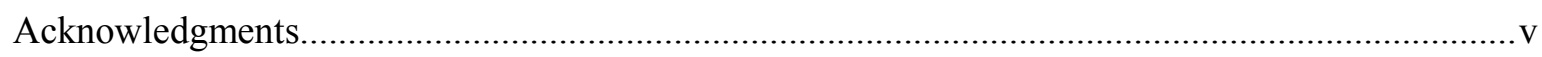

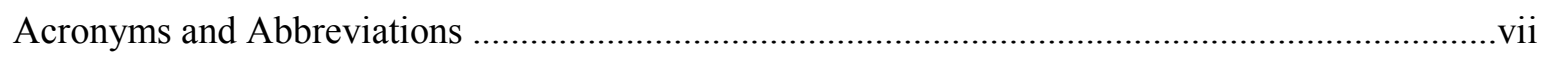

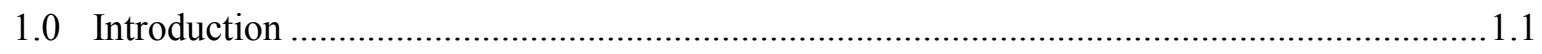

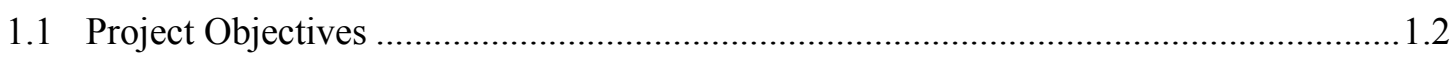

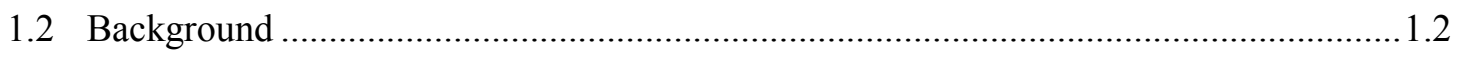

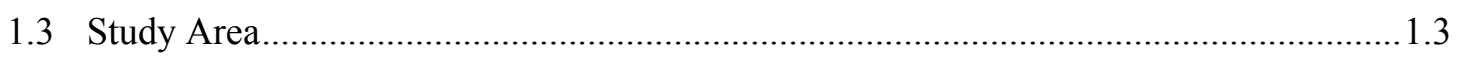

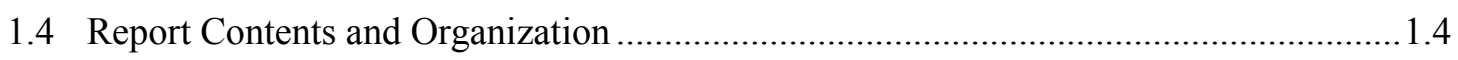

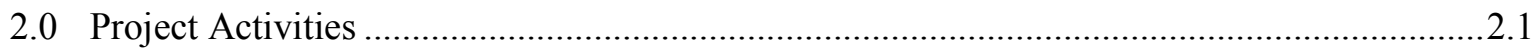

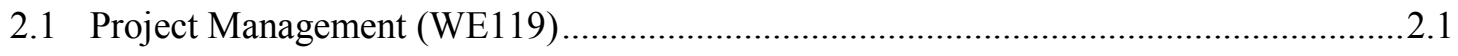

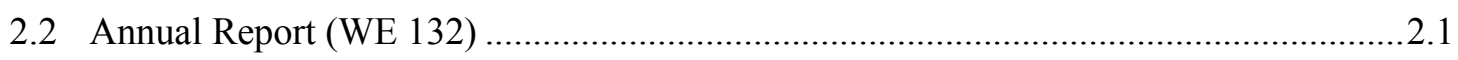

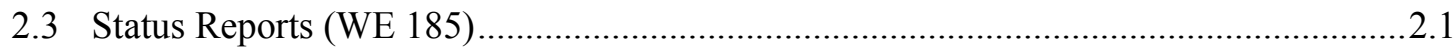

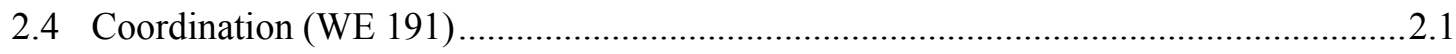

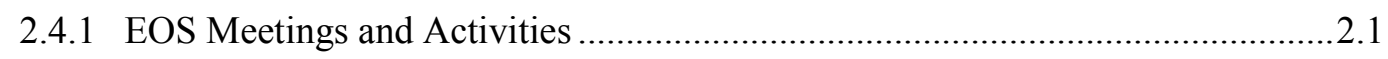

2.4.2 ERTG Meetings and Activities .................................................................. 2.1

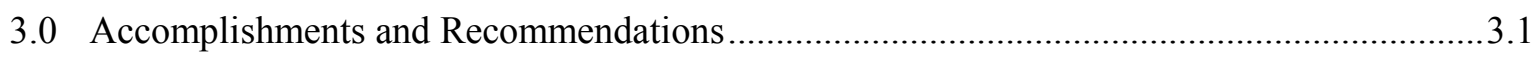

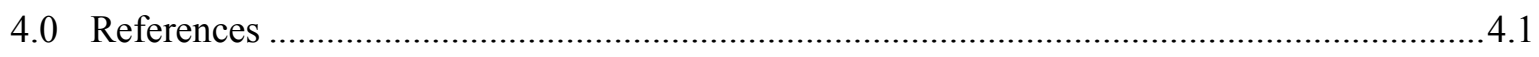

Appendix A Notes from Regional ERTG Meeting................................................................. 1

Appendix B Notes from ERTG/Steering Committee Meetings................................................. B. 1

\section{Figure}

Figure 1.1. Map of the Lower Columbia River and Estuary................................................. 1.1

\section{Tables}

Table 2.1. ERTG's Project Review Activities during FY13...................................................2.2

Table 2.2. Summary of ERTG's Project Review Activities: Number of Restoration Projects (Actions) for FY13 Total and Cumulative Total June 2009 through September 2013 , as Facilitated through Project 2002-077-00. 



\subsection{Introduction}

This document is the annual report for fiscal year 2013 (FY13) for the project called Facilitation of the Estuary/Ocean Subgroup (EOS) and the Expert Regional Technical Group (ERTG). Pacific Northwest National Laboratory (PNNL) conducted the project for the Bonneville Power Administration (BPA). The EOS and ERTG are part of the research, monitoring, and evaluation (RME) and habitat restoration efforts, respectively, developed by the Action Agencies (BPA, U.S. Army Corps of Engineers [Corps or USACE], and U.S. Bureau of Reclamation) in response to obligations arising from the Endangered Species Act as a result of operation of the Federal Columbia River Power System (FCRPS) and implemented under the Columbia Estuary Ecosystem Restoration Program (CEERP ${ }^{1}$ ). For the purposes of this report, the lower Columbia River and estuary (LCRE) includes the floodplain from Bonneville Dam down through the lower river and estuary into the river's plume in the ocean (Figure $1.1)$.

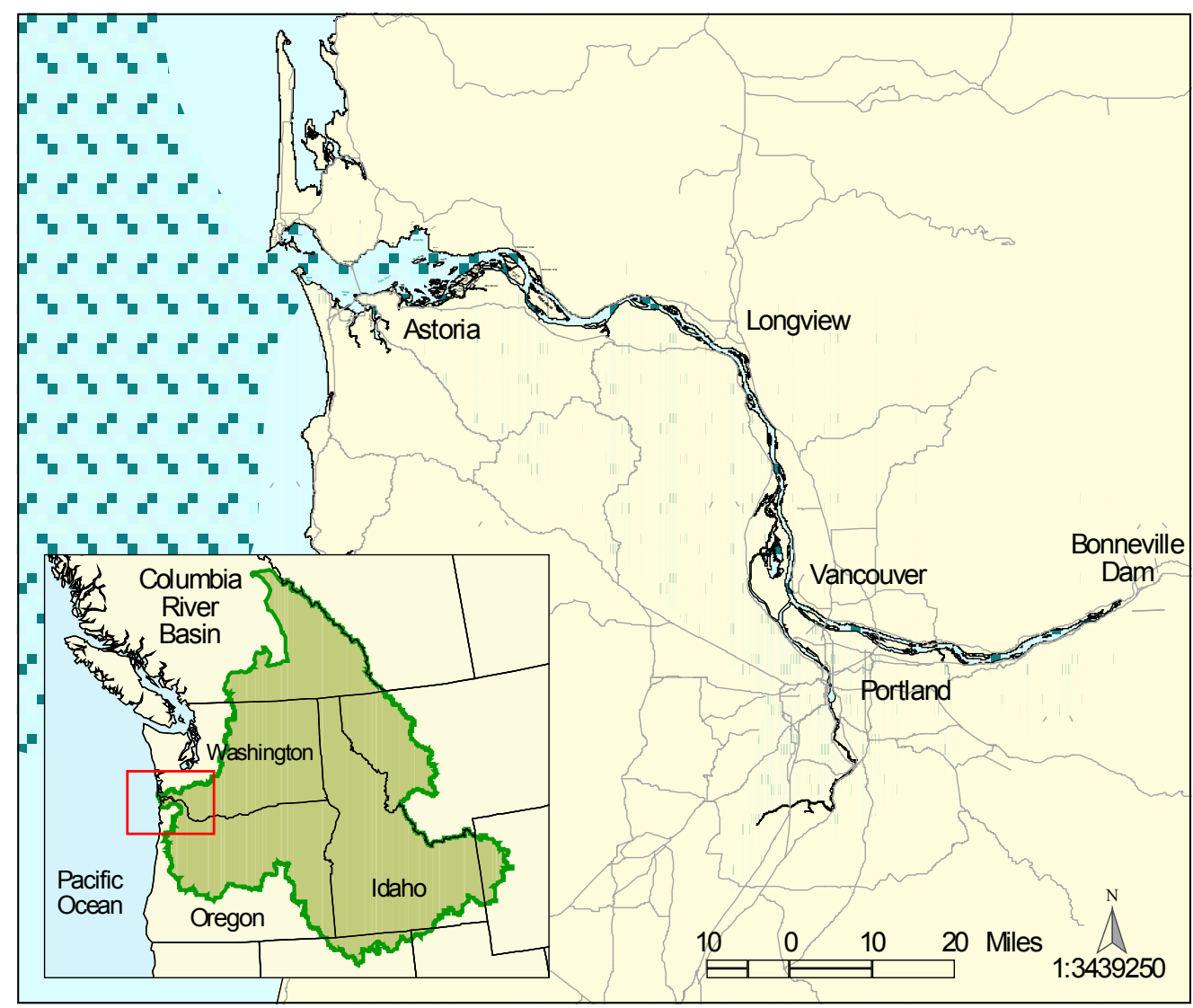

Figure 1.1. Map of the Lower Columbia River and Estuary.

The purpose of this project is to facilitate EOS and ERTG meetings and work products. The EOS is working to coordinate implementation of the Estuary RME Program with the Northwest Power and

\footnotetext{
${ }^{1}$ CEERP is an acronym coined in 2011 for the joint BPA/Corps efforts to restore LCRE ecosystems that started with the 2000 Federal Columbia River Power System (FCRPS) Biological Opinion (BiOp) (NMFS 2000) and now is responsive to subsequent FCRPS BiOps, the Council's Fish and Wildlife Program, and various Corps restoration authorities. BPA/Corps (2012a, 2012b) explain the CEERP and the role of RME and the ERTG.
} 
Conservation Council's (Council's) Fish and Wildlife Program, federal RME parties, and other federal and non-federal entities conducting RME in the estuary. From 2002 through 2008, the EOS worked to design the federal RME program for the estuary/ocean (Johnson et al. 2008). From 2009 to the present day, EOS activities have involved RME implementation.

The ERTG assigns survival benefit units ${ }^{2}$ for ocean- and stream-type juvenile salmon from estuary habitat actions implemented by the Action Agencies (AAs) as called for in the 2008 Biological Opinion (BiOp) of Federal Columbia River Power System Operations. The ERTG has been operational since 2009. It is directed by a steering committee composed of representatives from BPA, National Marine Fisheries Service (NMFS), and USACE. BPA/Corps (2012c) describe the ERTG and the role science plays in the process to assign survival benefit units to habitat restoration projects in the LCRE.

\subsection{Project Objectives}

The project had the following objectives for FY13, designated by work element (WE) codes from BPA's Pisces ${ }^{3}$ project tracking system as of October 1, 2010:

- Manage and Administer Projects (WE 119). Manage and administer the project according to BPA's "Work Element/Milestone" based project management and reporting system (Pisces).

- Produce Annual Report (WE 132). Produce an annual report of project activities, including under separate cover a pilot synthesis report of estuary/ocean RME as part of adaptive management at the program level.

- Produce Status Report (WE 185). Produce quarterly status reports and upload them to Pisces.

- Provide Watershed Coordination (WE 191). Much of the scope of work for this project (No. 2002-077-00) is coordination of RME and ERTG activities in the LCRE as part of the CEERP, as follows:

- $191 \mathrm{a}$ - Estuary/Ocean Subgroup for Federal RME. Continue to facilitate the EOS in its mission to implement the Estuary RME Program.

- $191 \mathrm{~b}$ - Expert Regional Technical Group. Aid the AAs as they continue the ERTG's work to assess survival benefits to juvenile salmon from habitat restoration in the LCRE. Convene and coordinate with subcontractors who will be members of the ERTG.

\subsection{Background}

The function of the LCRE in the life history of threatened and endangered salmonids is more than simply serving as a corridor for passage between the tributaries and the Pacific Ocean (Bottom et al. 2005; Sather et al. 2009). The estuary provides habitat for multiple life-history stages of salmon and steelhead, ranging from the rearing and feeding of fry, fingerlings, and smolts to the passage upstream of adults (Bottom et al. 2005). Use of estuary habitats by juvenile salmonids varies by species and life-

\footnotetext{
${ }^{2}$ A survival benefit unit (SBU) is an index intended to represent the effect of LCRE habitat restoration on juvenile salmon survival (ERTG 2010a). The SBU method uses an ecosystem-based approach to assess improvements to habitats supporting juvenile salmon and other species. SBUs are assigned on a restoration project-specific basis.

${ }^{3}$ Pisces is a database application for project management for the BPA Fish and Wildlife Division.
} 
history stage (Rich 1920). Generally, the closer the natal stream is to the estuary and the smaller the juvenile migrant, the more likely it is that juveniles will use estuarine habitats as feeding, rearing, and refuge areas, i.e., as more than just a migration corridor (Dawley et al. 1986). Information about salmon biology and ecology in the Columbia River estuary can be found in reports by Bottom et al. $(1984,2005)$, Dawley et al. (1985a, b, 1986), Kirn et al. (1986), Ledgerwood et al. (1991), McCabe et al. (1983, 1986), McConnell et al. (1983), and Reimers and Loeffel (1967). Thom et al. (2012) recently synthesized and evaluated information relevant to juvenile salmon in the LCRE.

In recognition of the estuary's importance to salmon population viability, the 2008 and 2010 BiOps on operation of the FCRPS called for the restoration of estuarine habitat as a pivotal action to avoid jeopardizing the continued existence of listed salmonid populations (NMFS 2008, 2010), as well as comprehensive RME for listed salmon. As a result of the $2000 \mathrm{BiOp}$ on FCRPS operations, the AAs and NMFS established a process for developing a basin-wide plan to guide RME efforts in the tributaries, hydrosystem, and estuary/ocean. The process involves a Policy Oversight Group and six technical subgroups: Status Monitoring, Effectiveness Research, Hydrosystem, Hatchery/Harvest, Data Management, and Estuary/Ocean. In FY13, federal RME efforts involved implementing the RME provisions defined in the $2008 \mathrm{BiOp}$.

Overall in FY13, much of the work on the project concerned the ERTG and its role in the CEERP. Activities and accomplishments for the project during FY13 are documented in this annual report. Annual reports for the EOS/ERTG project were submitted for FY05 through FY12 (Johnson 2005, 2006; Johnson and Diefenderfer 2007, 2008; Johnson 2009, 2010, 2011, 2012). These reports are available from BPA (http://www.cbfish.org/Report.mvc/SearchPublications/SearchByTextAndAuthorAndDate).

\subsection{Study Area}

The LCRE is defined as the tidally influenced portion of the river from Bonneville Dam to the plume. This is consistent with Bottom et al. (2005). Lower Columbia River tributaries above tidal influence are not part of the estuary RME study area. The following publications provide descriptive information about the Columbia River estuary:

- the Salmon at River's End report by Bottom et al. (2005)

- Fresh et al.'s (2005) Role of the Estuary in the Recovery of Columbia River Basin Salmon and Steelhead

- the Corps' the Biological Assessment for the Columbia River Channel Improvements Project (USACE 2001)

- the Council's sub-basin plan for the estuary (Council 2005, 2009)

- recovery planning documents (Lower Columbia Fish Recovery Board 2010; NMFS 2011)

Important earlier compendiums include the following:

- The Columbia River Estuary and Adjacent Ocean Waters by Pruter and Alverson (1972)

- "Columbia River Estuary" in Changes in Fluxes in Estuaries: Implications from Science to Management by Dyer and Orth (1994) 
- Columbia River: Estuarine System by Small (1990), which contains reviews of earlier work supported by the Columbia River Estuary Data Development Program (CREDDP) on physical and biological processes (CREDDP 1984a, 1984b).

\subsection{Report Contents and Organization}

The ensuing sections of this FY13 annual report describe project activities, summarize accomplishments, and provide recommendations for FY13. The sections on activities and accomplishments are organized by the work elements listed previously under project objectives (Section 1.1). Notes from ERTG meetings and calls are contained in the appendices: regional ERTG meeting (Appendix A) and ERTG/Steering Committee (Appendix B). 


\subsection{Project Activities}

Activities during FY13 included project management, publishing the annual report and status reports, and coordination efforts, as described in the following sections for each work element (WE).

\subsection{Project Management (WE119)}

The project was managed according to procedures and principles set forth in PNNL's Standard Business and Management System. As requested by BPA, PNNL developed and submitted the FY13 scope of work and budget for Project 2002-077-00 to BPA via Pisces in August 2012.

\subsection{Annual Report (WE 132)}

This document fulfills the annual report objective.

\subsection{Status Reports (WE 185)}

PNNL submitted status reports on Project 2002-077-00 quarterly to BPA during FY13. The status reports contained information about whether progress in conducting the project was satisfactory. Status was assessed by milestone for each work element.

\subsection{Coordination (WE 191)}

The bulk of the work on the EOS/ERTG project falls under the coordination work element. The material that follows is organized by the topics listed under the coordination objective in Section 1.1.

\subsubsection{EOS Meetings and Activities}

During FY13, a subset of the EOS (BPA, Corps, PNNL) held several meetings to contribute to the Action Agencies' 2013 Comprehensive Evaluation and 2013 Implementation Plan. The bulk of work for these two efforts, however, was conducted by BPA and Corps staff independent of the EOS.

\subsubsection{ERTG Meetings and Activities}

During FY13, one regional ERTG meeting was held (on December 12, 2012, at the Northwest Power and Conservation Council in Portland, Oregon) to report on ERTG activities and disseminate results from the ERTG's review of restoration projects. The meeting entailed an open question/answer session between the ERTG and interested regional parties. Notes from the regional ERTG meeting are presented in Appendix A.

The ERTG and its Steering Committee met nine times over the course of FY13 to work on topics relevant to assigning survival benefit units to estuary habitat restoration projects. Notes from the ERTG/Steering Committee meetings are presented in Appendix B. (Appendix B also includes notes from 
the September 2012 meeting of the ERTG/Steering Committee, which was too late in FY12 to be included in the FY12 annual report.)

Bi-weekly conference calls for the Steering Committee were conducted to plan and coordinate ERTG activities. The results of these calls are reflected in the content of the regional ERTG and ERTG/Steering Committee meetings. The Steering Committee held 13 (as of 9/3/13) such calls in FY13.

During FY13, the ERTG received one work request from the Steering Committee: develop an approach to calculate SBUs for floodplain lake restoration projects. The ERTG worked on this request while performing its project review and scoring responsibilities. The document is titled, "Estimating Survival Benefit Units for Subactions Involving Floodplain Lakes" (ERTG 2013). It is scheduled for completion by September 30, 2013, and will be available from BPA (Ben Zelinsky) or the Corps (Blaine Ebberts). As part of this effort, several ERTG members participated in a workshop Role of Floodplain Lakes for Juvenile Salmonids in the Lower Columbia River and Estuary convened by the Lower Columbia Estuary Partnership and held June 18, 2013 in Portland, Oregon.

During FY13, the ERTG participated in 21 project presentations and 16 site visits (Table 2.1). They scored 21 projects from which 21 SBU reports were generated. Table 2.2 contains a summary of ERTG's cumulative and FY13 activities, as facilitated through Project 2002-077-00. Since its inception in June 2009, the ERTG has been involved in 54 project presentations, 45 site visits, 47 project scorings, and 43 SBU reports (Table 2.2).

Table 2.1. ERTG's Project Review Activities during FY13.

\begin{tabular}{|c|c|c|c|c|c|}
\hline Id' & Project Name & Presentation & Site Visit & Scoring & SBU Report \\
\hline 2012-01 NEW & Kandoll 2 & $\mathrm{x}$ & no & $\mathrm{x}$ & $\mathrm{x}$ \\
\hline 2012-03 NEW & Wallooskee-Youngs & $\mathrm{x}$ & previously & $\mathrm{x}$ & $\mathrm{x}$ \\
\hline 2012-05 & Dairy Creek/Sturgeon Lake & $\mathrm{x}$ & $\mathrm{x}$ & $\mathrm{x}$ & $\mathrm{x}$ \\
\hline $2012-06$ & Gnat Creek $(\mathrm{Ph} \mathrm{1)}$ & $\mathrm{x}$ & $\mathrm{x}$ & $\mathrm{x}$ & $\mathrm{x}$ \\
\hline 2012-07 & South Tongue Point & $\mathrm{x}$ & $\mathrm{x}$ & $\mathrm{x}$ & $\mathrm{x}$ \\
\hline 2012-08 & Colewort & $\mathrm{x}$ & $\mathrm{x}$ & $\mathrm{x}$ & $\mathrm{x}$ \\
\hline 2012-09 & Honeyman & $\mathrm{x}$ & $\mathrm{x}$ & $\mathrm{x}$ & $\mathrm{x}$ \\
\hline $2012-10$ & Wapato Access & $\mathrm{x}$ & $\mathrm{x}$ & $\mathrm{x}$ & $\mathrm{x}$ \\
\hline 2013-01 & Dibblee Point & $\mathrm{x}$ & $\mathrm{x}$ & $\mathrm{x}$ & $\mathrm{x}$ \\
\hline 2013-02 & Oaks Bottom & $\mathrm{x}$ & $\mathrm{x}$ & $\mathrm{x}$ & $\mathrm{x}$ \\
\hline 2013-03 & Post Office Lake & $\mathrm{x}$ & $\mathrm{x}$ & $\mathrm{x}$ & $\mathrm{x}$ \\
\hline 2013-04 & $\begin{array}{c}\text { Sandy River Delta -- Dam } \\
\text { Removal }\end{array}$ & $\mathrm{x}$ & previously & $\mathrm{x}$ & $\mathrm{x}$ \\
\hline 2013-05 & North Unit (Ph 1) Ruby & $\mathrm{x}$ & $\mathrm{x}$ & $\mathrm{x}$ & $\mathrm{x}$ \\
\hline 2013-06 & North Unit (Ph 1) Millionaire & $\mathrm{x}$ & no & $\mathrm{x}$ & $\mathrm{x}$ \\
\hline 2013-07 & LA Swamp & $\mathrm{x}$ & $\mathrm{x}$ & $\mathrm{x}$ & $\mathrm{x}$ \\
\hline 2013-08 & Horsetail & $\mathrm{x}$ & $\mathrm{x}$ & $\mathrm{x}$ & $\mathrm{x}$ \\
\hline 2013-09 & Steigerwald & $\mathrm{x}$ & $\mathrm{x}$ & $\mathrm{x}$ & $\mathrm{x}$ \\
\hline $2013-10$ & Gnat Creek $(\mathrm{Ph} 2)$ & $\mathrm{x}$ & $\mathrm{x}$ & $\mathrm{x}$ & $\mathrm{x}$ \\
\hline 2013-11 & North Unit (Ph 1) Widgeon/Deep & $\mathrm{x}$ & no & $\mathrm{x}$ & $\mathrm{x}$ \\
\hline 2013-12 & Trestle Bay & $\mathrm{x}$ & $\mathrm{x}$ & $\mathrm{x}$ & $\mathrm{x}$ \\
\hline
\end{tabular}




\begin{tabular}{cccccc}
\hline Id' & Project Name & Presentation & Site Visit & Scoring & SBU Report \\
\hline $2013-13$ & Steamboat Slough & $\mathrm{x}$ & $\mathrm{x}$ & $\mathrm{x}$ & $\mathrm{x}$ \\
\hline Total & & $\mathbf{2 1}$ & $\mathbf{1 6}$ & $\mathbf{2 1}$ & $\mathbf{2 1}$ \\
\hline
\end{tabular}

Table 2.2. Summary of ERTG's Project Review Activities: Number of Restoration Projects (Actions) for FY13 Total and Cumulative Total June 2009 through September 2013, as Facilitated through Project 2002-077-00.

\begin{tabular}{lc}
\hline Activity & $\begin{array}{c}\text { Cumulative Total } \\
(6 / 1 / 09\end{array}$ \\
& thru 9/30/13) \\
\hline Sponsor presentations & 54 \\
Site visits & 45 \\
Scorings & 47 \\
SBU reports & 43 \\
\hline
\end{tabular}





\subsection{Accomplishments and Recommendations}

During FY13, accomplishments for BPA Project 2002-077-00 included the following:

- Continued to facilitate and document activities of the ERTG and its Steering Committee.

- Coordinated ERTG's work to produce an approach to calculating SBUs for floodplain lake reconnection projects (ERTG Doc\#2013-01).

- Organized, convened, facilitated, and documented 1 regional ERTG meeting, 9 ERTG/Steering Committee meetings or calls, and 13 Steering Committee conference calls.

- Gave a presentation about the ERTG at the 2013 National Conference on Ecosystem Restoration in Chicago, Illinois. (Funding in part provided by the Corps.)

Recommended project work in FY14 includes continued facilitation of the EOS and ERTG, as follows:

- Continue to facilitate the EOS in its mission to implement the RME component of CEERP.

- Aid the AAs as they continue the ERTG's work to assess survival benefits to juvenile salmon from habitat restoration in the LCRE under the CEERP. 



\subsection{References}

Note: the references below include ERTG documents that are cited in meeting notes in the appendices.

Bottom DL, KK Jones, and JJ Herring. 1984. Fishes of the Columbia River Estuary. Columbia River Data Development Program, Columbia River Estuary Study Taskforce, Astoria, Oregon.

Bottom DL, CA Simenstad, J Burke, AM Baptista, DA Jay, KK Jones, E Casillas, and MH Schiewe. 2005. Salmon at River's End: The Role of the Estuary in the Decline and Recovery of Columbia River Salmon. NOAA Technical Memorandum National Oceanic and Atmospheric Administration (NOAA) Fisheries-NWFSC-68, Northwest Fisheries Science Center, Seattle, Washington.

BPA/Corps (Bonneville Power Administration and US Army Corps of Engineers). 2012a. Columbia Estuary Ecosystem Restoration Program: 2012 Strategy Report. Final report, Bonneville Power Administration and U.S. Army Corps of Engineers, Portland, Oregon.

BPA/Corps (Bonneville Power Administration and US Army Corps of Engineers). 2012b. Columbia Estuary Ecosystem Restoration Program: 2012 Action Plan. Final report, Bonneville Power Administration and U.S. Army Corps of Engineers, Portland, Oregon.

BPA/Corps (Bonneville Power Administration and US Army Corps of Engineers). 2012c. Role of Science and Process for the Expert Regional Technical Group to Assign Survival Benefit Units for Estuary Habitat Restoration Projects. Final report, Bonneville Power Administration and U.S. Army Corps of Engineers, Portland, Oregon.

Columbia River Estuary Data Development Program (CREDDP). 1984a. Index to CREDDP Data. Compiled by HT Mercier; S. Bell (ed.), Columbia River Estuary Study Taskforce, Astoria, Oregon.

Columbia River Estuary Data Development Program (CREDDP). 1984b. Abstracts of Major CREDDP Publications. Compiled by D Fox, Columbia River Estuary Study Taskforce, Astoria, Oregon.

Council (Northwest Power and Conservation Council). 2005. "Lower Columbia Subbasin Plan." In Columbia River Basin Fish and Wildlife Program. Portland, Oregon.

Council (Northwest Power and Conservation Council). 2009. Columbia River Basin Fish and Wildlife Program. Council Document 2009-09, Portland, Oregon. Available at http://www.nwcouncil.org/library/ 2009/2009-09/.

Dawley EM, RD Ledgerwood, and AL Jensen. 1985a. Beach and Purse Seine Sampling of Juvenile Salmonids in the Columbia River Estuary and Ocean Plume, 1977-1983; Volume I; Procedures, Sampling Effort and Catch Data. NOAA Technical Memorandum F/NWC-74:1-260, National Oceanic and Atmospheric Administration (NOAA) Fisheries, Seattle, Washington.

Dawley EM, RD Ledgerwood, and AL Jensen. 1985b. Beach and Purse Seine Sampling of Juvenile Salmonids in the Columbia River Estuary and Ocean Plume, 1977-1983; Volume II; Data on Marked Fish Recoveries. NOAA Technical Memorandum F/NWC-75:1-397, National Oceanic and Atmospheric Administration (NOAA) Fisheries, Seattle, Washington. 
Dawley EM, RD Ledgerwood, TH Blahm, CW Sims, JT Durkin, RA Kirn, AE Rankis, GE Monan, and FJ Ossiander. 1986. Migrational Characteristics, Biological Observations, and Relative Survival of Juvenile Salmonids Entering the Columbia River Estuary, 1966-1983. Prepared by the National Marine Fisheries Service, Northwest Fisheries Science Center, Seattle, Washington.

Dyer KR and RJ Orth (eds.). 1994. Changes in Fluxes in Estuaries: Implications from Science to Management. Proceedings of ECSA22/ERF Symposium, 13-18 September 1992, Institute of Marine Studies, University of Plymouth. Olsen \& Olsen, Fredensborg, Denmark.

ERTG (Expert Regional Technical Group). 2010a. History and Development of the SBU Calculator. Document \# ERTG 2010-03, available from Bonneville Power Administration or the U.S. Army Corps of Engineers, Portland, Oregon.

ERTG (Expert Regional Technical Group). 2010b. Scoring Criteria. Document \# ERTG 2010-02, available from Bonneville Power Administration or the U.S. Army Corps of Engineers, Portland, Oregon.

ERTG (Expert Regional Technical Group). 2012a. ERTG Analysis of Water Levels for Site Delineation in Tidal Dominated Regions. Document \# ERTG 2012-01, available from Bonneville Power Administration or the U.S. Army Corps of Engineers, Portland, Oregon.

ERTG (Expert Regional Technical Group). 2012b. ERTG Uncertainties. Document \# ERTG 2012-02, available from Bonneville Power Administration or the U.S. Army Corps of Engineers, Portland, Oregon.

ERTG (Expert Regional Technical Group). 2012c. ERTG Template for LCRE Habitat Restoration Project Summary. Document \# ERTG 2010-01 rev 2, available from Bonneville Power Administration or the U.S. Army Corps of Engineers, Portland, Oregon.

ERTG (Expert Regional Technical Group). 2013. Estimating Survival Benefit Units for Subactions Involving Floodplain Lakes. Document \# ERTG 2013-01, available from Bonneville Power Administration or the U.S. Army Corps of Engineers, Portland, Oregon.

Fresh KL, E Casillas, LL Johnson, and DL Bottom. 2005. Role of the Estuary in the Recovery Columbia River Basin Salmon and Steelhead: An Evaluation of Selected Factors on Salmonid Population Viability. NOAA Technical Memorandum NMFS-NWFSC-69, National Oceanic and Atmospheric Administration (NOAA) Fisheries, Northwest Fisheries Science Center, Seattle, Washington.

Johnson G. 2005. Estuary/Ocean Research, Monitoring, and Evaluation Support Project: FY05 Annual Report. Final report prepared for the Bonneville Power Administration, Portland, Oregon, by the Pacific Northwest National Laboratory, Richland, Washington.

Johnson G. 2006. Facilitation of the Estuary/Ocean Subgroup for Research, Monitoring, and Evaluation, FY06 Annual Report. PNNL-16142, final report prepared for the Bonneville Power Administration, Portland, Oregon, by the Pacific Northwest National Laboratory, Richland, Washington.

Johnson G. 2009. Facilitation of the Estuary/Ocean Subgroup for Research, Monitoring, and Evaluation, FY09 Annual Report. PNNL-18907, final report prepared for the Bonneville Power Administration, Portland, Oregon, by the Pacific Northwest National Laboratory, Richland, Washington. 
Johnson G. 2010. Facilitation of the Estuary/Ocean Subgroup for Research, Monitoring, and Evaluation, FY10 Annual Report. PNNL-19940, final report prepared for the Bonneville Power Administration, Portland, Oregon, by the Pacific Northwest National Laboratory, Richland, Washington.

Johnson G. 2011. Facilitation of the Estuary/Ocean Subgroup for Research, Monitoring, and Evaluation, FY11 Annual Report. PNNL-20744, final report prepared for the Bonneville Power Administration, Portland, Oregon, by the Pacific Northwest National Laboratory, Richland, Washington.

Johnson G. 2012. Facilitation of the Estuary/Ocean Subgroup for Research, Monitoring, and Evaluation, FY11 Annual Report. PNNL-21634, final report prepared for the Bonneville Power Administration, Portland, Oregon, by the Pacific Northwest National Laboratory, Richland, Washington.

Johnson GE and HL Diefenderfer. 2007. Facilitation of the Estuary/Ocean Subgroup for Research, Monitoring, and Evaluation, FY07 Annual Report. PNNL-16947, final report prepared for the Bonneville Power Administration, Portland, Oregon, by the Pacific Northwest National Laboratory, Richland, Washington.

Johnson GE and HL Diefenderfer. 2008. Facilitation of the Estuary/Ocean Subgroup for Research, Monitoring, and Evaluation, FY08 Annual Report. PNNL-17811, final report prepared for the Bonneville Power Administration, Portland, Oregon by the Pacific Northwest National Laboratory, Richland, Washington.

Johnson GE, HL Diefenderfer, BD Ebberts, C Tortorici, T Yerxa, J Leary, and J Skalski. 2008. Research Monitoring and Evaluation for the Federal Columbia River Estuary Program. PNNL-17300, final report prepared for the Bonneville Power Administration, Portland, Oregon, by the Pacific Northwest National Laboratory, Richland, Washington.

Kirn RA, RD Ledgerwood, and AL Jensen. 1986. "Diet of Subyearling Chinook Salmon (Oncorhynchus tshawytscha) in the Columbia River Estuary and Changes Effected by the 1980 Eruption of Mount St. Helens." Northwest Science 60:191-196.

Ledgerwood RD, FP Thrower, and EM Dawley. 1991. "Diel sampling of migratory juvenile salmonids in the Columbia River estuary." Fisheries Bulletin 89:69-78.

Lower Columbia Fish Recovery Board. 2010. 2010 Lower Columbia Salmon Recovery and Fish \& Wildlife Subbasin Plan. Revision of the 2006 interim recovery plan for the Washington portion of the lower Columbia River recovery domain. Available at www.lcrfb.org.

McCabe GT Jr, WD Muir, and JT Durkin. 1983. "Interrelationships between juvenile salmonids and nonsalmonid fish in the Columbia River Estuary." U.S. Bur. Fish. Bull. 81:815-826.

McCabe GT Jr, RL Emmett, WD Muir, and TH Blahm. 1986. "Utilization of the Columbia River Estuary by Subyearling Chinook Salmon.” Northwest Science 60(2):113-124.

McConnell R, T Blahm, G McCabe, T Clocksin, T Coley, J Durkin, R Emmett, and W Muir. 1983. Columbia River Estuary Data Development Program Data Report: Salmonid and Non-Salmonid Fish, four volumes. Columbia River Estuary Data Development Program, managed by Columbia River Estuary Taskforce, Astoria, Oregon. 
National Marine Fisheries Service (NMFS). 2008. Biological Opinion-Consultation on Remand for Operation of the Federal Columbia River Power System, 11 Bureau of Reclamation Projects in the Columbia Basin and ESA Section 10(a)(1)(A) Permit for Juvenile Fish Transportation Program. National Marine Fisheries Service (NOAA Fisheries) - Northwest Region. Seattle, Washington.

National Marine Fisheries Service (NMFS). 2010. Endangered Species Act Section 7(a)(2) Consultation Supplemental Biological Opinion Supplemental Consultation on Remand for Operation of the Federal Columbia River Power System, 11 Bureau of Reclamation Projects in the Columbia Basin and ESA Section 10(a)(I)(A) Permit for Juvenile Fish Transportation Program. NMFS - Northwest Region, Seattle, Washington.

National Marine Fisheries Service (NMFS). 2011. Columbia River Estuary ESA Recovery Plan Module for Salmon and Steelhead. NMFS Northwest Region, Seattle, Washington. Available at http://www.nwr.noaa.gov/Salmon-Recovery-Planning/ESA-Recovery-Plans/Estuary-Module.cfm.

Pruter AT and DL Alverson (eds.). 1972. The Columbia River Estuary and Adjacent Ocean Waters: Bioenvironmental Studies. University of Washington Press, Seattle, Washington.

Reimers PE and RE Loeffel. 1967. "The Length of Residence of Juvenile Fall Chinook Salmon in Selected Columbia River Tributaries.” Res. Briefs, Fish Comm. Oreg. 13(1):5-19.

Rich WH. 1920. "Early history and seaward migration of Chinook salmon in the Columbia and Sacramento rivers." U.S. Bur. Fish. Bull. 37:2-73.

Sather NK, GE Johnson, AJ Storch, DJ Teel, JR Skalski, TA Jones, EM Dawley, SA Zimmerman, AB Borde, C Mallette, and R Farr. 2009. Ecology of Juvenile Salmon in Shallow Tidal Freshwater Habitats in the Vicinity of the Sandy River Delta, Lower Columbia River, 2008. PNNL-18450, final report submitted to the Bonneville Power Administration by Pacific Northwest National Laboratory, Oregon Department of Fish and Wildlife, National Marine Fisheries Service, and University of Washington, Richland, Washington.

Small LF (ed.). 1990. “Columbia River: Estuarine System.” Progress in Oceanography 25(1-4).

Thom RT, NK Sather, D Bottom, and GC Roegner. 2012. Columbia Estuary Ecosystem Restoration Program: 2012 Synthesis Memorandum. Draft final report submitted to U.S. Army Corps of Engineers, Portland, Oregon.

U.S. Army Corps of Engineers (USACE). 2001. Biological Assessment Columbia River Channel Improvements Project. Prepared for the National Oceanic and Atmospheric Administration Fisheries and U.S. Fish and Wildlife Service, by the U.S. Army Corps of Engineers, Portland, Oregon. 
Appendix A

Notes from Regional ERTG Meeting 


\section{Appendix A}

\section{Notes from Regional ERTG Meeting}

This appendix contains notes from the one regional ERTG meeting during FY13.

\section{ERTG Meeting Notes}

ERTG: The Expert Regional Technical Group for Federal Estuary Habitat Actions (RPA 37)

Meeting Date: December 12, 2012

Location: NPPC Offices, Portland, OR

Participants:

- ERTG Members: Hood (Skagit River System Cooperative), Jones (ODFW), Krueger (WDFW), and Thom (PNNL)

- Steering Committee: Doumbia and Zelinsky (BPA) and Ebberts and Studebaker (Corps)

- Support Personnel: Johnson (PNNL) and Trask (PC Trask and Associates)

- Interested Parties: Corbett (LCEP), Jorgensen (Cowlitz Tribe consultant), Kolp (LCEP), Kruger (ODFW), Munro (Tetra Tech), O’Toole (NPCC), Runyon (Cascade Environmental Group), Salakory (phone), Schwartz (LCEP), Siegel (Tetra Tech), Sinks CLT), Van Ess (phone; CREST)

Purpose: ERTG outreach and information exchange.

\section{Agenda}

Introduction

- Purpose, topics, and expected outcome

- ERTG work in 2012

ERTG Work Products (2012)

- ERTG Uncertainties (Doc \#ERTG 2012-01)

- ERTG Analysis of Water Levels for Site Delineation in Tidal Dominated Regions (Doc \#ERTG 2012-02)

- Project Template (revised) (Doc \#ERTG 2010-01)

ERTG SBU Reports (2012 projects)

- Kandoll 2

- Abernathy Ck

- Youngs-Walluski

- Deer Island

- Gnat Ck

- South Tongue Point 
- Colewort

Anticipated Future Work

- Habitat creation projects

- Floodplain lakes

- Subaction implementation emphasis

- GIS prioritization and planning tools

Questions/Answers and Open Discussion

Adjourn

\section{Notes}

The following notes are key points from the meeting; they are not intended to be meeting minutes.

\section{Introduction}

Purpose, Topics, Expected Outcome

- Purpose $=$ Review ERTG process, and disseminate and discuss the SBU reports for 20 projects.

- Topics $=$ Review the process for calculating SBUs in the morning and SBU reports in the afternoon.

- Expected outcome = Understanding of the SBU reports and what the ERTG does and has done.

\section{ERTG Work Products}

ERTG Uncertainties (Doc \#ERTG 2012-01) -- Hood

- Highlighted some of the uncertainties the ERTG listed.

- LWD -- translating paradigm from stream ecosystems to tidal ecosystems. Also, have piscivorous fish - is it a net benefit or impact?

- Pilings -- don't know the ecological role of pilings. Certainly want to remove pilings that are leaching pollutants.

- Tidal wetlands -- need empirical models to predict tidal wetland development. Useful for planning and engineering. Also, need models of veg vs elevation, salinity, etc.

- Floodplain lakes and ponds -- lots of info from tropical systems but not temperate systems. Not well-understood of how they affect juvenile salmon.

- Corbett -- pilings -- did do a pilot study of the leaching from contaminated pilings and did not find many that seemed to be leaching pollutants. Lot's of pilings not even treated to begin with. Ones that were had already leached out the preservatives. Question was what kind of benefit or ERTG scores would they get.

- Q: Status of piling work in Corps? A: Established PDT, and two white papers are under construction. Two issues: predation and habitat. Due near end of year.

- Q: Explain more about the predictive models? A: GH One example is to apply a model using tidal prism as a independent variable, along with others to predict X-sec area, veg, etc. See Hood 2007 Water Resources Research. 
- Q: Use of the uncertainties doc? A: Using it to support a criterion in AEMR prioritization. Also, uncertainty is part of the scoring for SBUs.

- Q: Discuss spatial distribution of habitats in context of 1100 -acre site is better than 1010 -acre sites? A: GH -- General point from theory. There are pro's and con's to different spatial configurations. Don't have specific studies addressing this for estuary restoration. Do have evidence from other systems.

ERTG Analysis of Water Levels for Site Delineation in Tidal Dominated Regions (Doc \#ERTG 2012-02) -- Thom

- RT described the work. Wanted to have a standard WSE approach to use to calculate wetted area for proposed restoration projects.

- Trask: One can interpolate between the data points in Table 1.

- Q: This is for the main stem, right? A: Yes.

- Comment: Kolp, also have projects collecting WSE data. RT -- need $10 \mathrm{y}$.

- TODO -- BDE to check w/ Corps on how the Multnomah Channel was incorporated in the analysis for Table 1 .

- Studebaker: Borde working of elev vs veg relationships. To be released in early 2013. Will be useful to restoration project planners.

Project Template (revised) (Doc \#ERTG 2010-01)

- Corbett: How about the change analysis results, maybe include in future versions? A: BDZ: intend to show the ERTG the tools. May include at a future data. Feel free to include info' now. Corbett: the data for Levels 1, 2, 3 (e.g., habitat change analysis) are on the LCEP website.

\section{ERTG SBU Reports (2012 projects)}

- $\quad$ Kandoll 2

- Q (Sinks): Did the ERTG consider the fish data from the CE study: A: yes

$\circ$ Q: Net change from Kan 1? A: BDZ, no, plan to return the SBUs for Kan 1 and use the SBU's from Kan 2.

○ Sinks: reconsidering closing the Kan 1 culverts.

- BDZ: Process with ERTG involves pre-restoration feedback from ERTG; also have loop in process that allows for rescoring if there's a significant change in the project.

- PROCESS Q -- Salakory: What about scoring each project at the as-built stage? BDZ: Not as a matter of routine, but it's possible if the project as-built was quite different than what the ERTG scored originally.

- GH: Significant design change w/ significant ecological implications should be rereviewed.

- BDZ: Criterion might be how much the project goal map changes, or other special considerations. KK: Also, look at comments and items that caused a low score; if those are fixed, might warrant a rescore.

- BACK to KAN 2.

○ Sinks: lot's more info' to use in the decision-making. 
- Next steps re: rescoring $=$ Sinks (sponsor) to work w/ BPA (funding agency) and decide next steps.

- $\quad$ Abernathy $\mathrm{Ck}$

$\circ$ No questions.

- $\quad$ Youngs-Walluski

- Note, fringe along the uplands will be planted. May add some topographical diversity and special plantings.

○ Jorgensen: Is there credit for allowing natural processes to restore vegetation?

- GH: See disposal of excavated material as a recurring issue. One suggestion is to recreate natural berms. Size of berm (or natural levees) is correlated with the size of the tidal channels. Measure some in a reference system to design how high to make them. Don't over-berm the channel. One way to get topographic diversity in the natural landform.

- RT: Often a barrow ditch that can be refilled with material.

- KJ: Plan to excavate to depth but not to width, and let tidal forces set the width. This will reduce the amount of material to dispose of. RT: regarding wood, at Kan 1, reconnections exposed buried wood, and created a step-pool structure.

- BDZ: Note, ERTG did a prelim score on this because it was early in the design. Plan to come back for a final

- BDZ: As a point of process, occasionally bring projects that are big, uncertain, costly, or new type of project never scored before.

- $\quad$ Deer Island

- TODO GEJ/BDZ to contact the guys from Deer (they didn't know about the ERTG mtg). TODO -- add Gorman to ERTG interested parties list.

- $\quad$ Gnat Ck

- No questions.

- $\quad$ South Tongue Point

$\circ$ No questions.

- $\quad \underline{\text { Colewort }}$

Q Q: Explain why scrape-down was not a Subaction 6.3, and instead was a Subaction 10.1. A: GH: beneficial use is really created habitat; taking fill out of a wetland that previously did exist. Effect is to restore access of fish to a tidal marsh, therefore a 10.1. Big difference between restoring pre-existing marshes as opposed to creating habitat where none existed before. KK: Also, lots more uncertainty with the later. ERTG is really scoring the anticipated effects of juvenile salmon. GH: Some action have a better track record than others; i.e., have less uncertainty.

\section{Anticipated Future Work}

- $\quad$ Habitat creation projects -- BDE

- Two reports out: 1) summary of accidental creation; 2) habitat creation guidelines. 
- Corps has two projects underway in feasibility/design: Miller Sands and Lois Island.

- Anticipate bringing habitat creation projects to the ERTG eventually.

- Timeline $=$ something for ERTG to evaluate in next 3-4 mon.

- See BDE for doc' on creation guidelines.

- $\quad$ Floodplain Lakes -- BDE

- New type of project. Asked ERTG to evaluate these projects.

$\circ$ Q: Corbett: How many floodplain lakes are there in the system? How big is this issue?

A: Big. This type of project could have lots of acreage.

- Corbett: Is there a size threshold? A: TBD.

- KK: Thinking about a habitat type and the engineering actions proposed and how the two interact.

- GH: Changed habitat diversity, distribution of shallow areas, etc. Habitat maybe not lost, just been redistributed perhaps.

- $\quad$ Subaction implementation emphasis -- BDZ

- Implementing ecosystem restoration within CEERP adaptive management framework.

- ERTG part of the AM process; feedback to decision-makers on the restoration actions.

- Shift in AAs priorities over time.

- One management implication: Subaction 10.1 dike breaches are a priority.

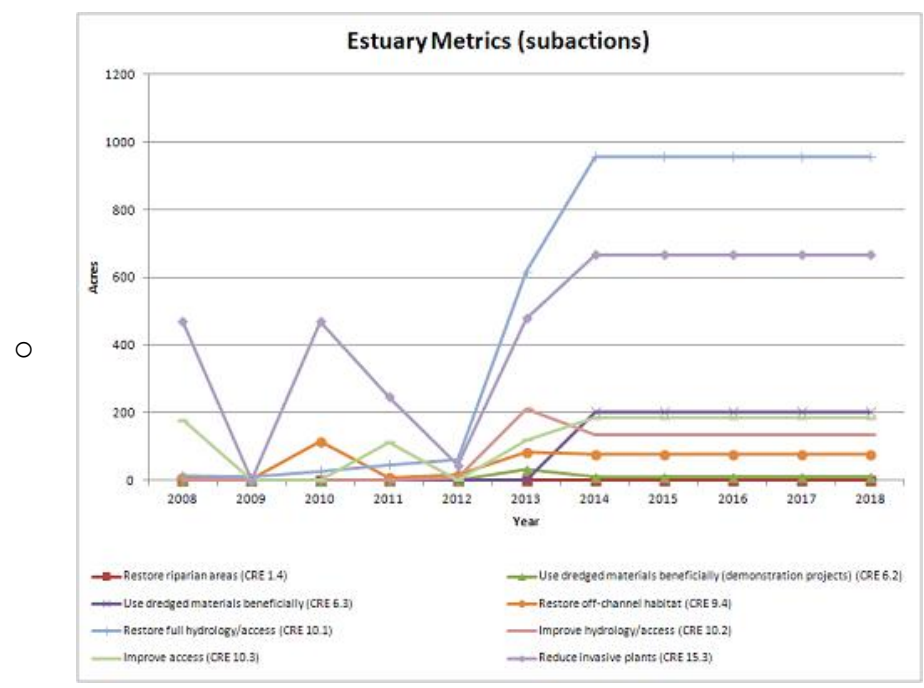

○ $\quad$ Years $=$ completed years.

- BDZ: BPA is tracking the estuary implementation in cbfisg.org. Soon to be publically accessible.

- $\quad$ GIS prioritization and planning tools -- BDZ

- Examples include: Habitat change Analysis, Landscape Planning Framework, etc. May bring these products to the ERTG to get there feedback. 
- How might some of the tools b e integrated into the ERTG process, e.g., a component of the template.

\section{Questions/Answers and Open Discussion}

- KJ: How is the ERTG considering large projects in the context of the landscape?

- RT: considers proximity to main stem in terms of landscape. Also, a nexus of tributaries. Along the longitudinal gradient, have not established any priorities.

- This gets subsumed into the access criterion and location in the system.

- GH: ERTG has adjusted scoring to take into account density of restoration actions within a given landscape.

- KK: If a project is part of a group of projects, consider this to be good. But there's no quantitative data on this. Take each project at face value in its landscape; no priority landscapes.

- KJ: How is the ERTG considering projects in terms of the reach survival data?

- Data are for tagged fish $>95 \mathrm{~mm}$.

- Lowest survival in lower $35 \mathrm{~km}$ attributed to bird predation.

\section{Next Meeting}

- Next regional ERTG meeting -- TBD. 



\section{Appendix B}

\section{Notes from ERTG/Steering Committee Meetings}





\section{Appendix B}

\section{Notes from ERTG/Steering Committee Meetings}

This appendix cover the nine meetings or calls of the ERTG and Steering Committee during FY13. Notes for each event were disseminated soon after the meetings or calls occurred. (The notes from the September 2012 meeting are included here because were too late to be included in the FY12 EOS/ERTG annual report.)

\section{B.1 ERTG/SC September 25 \& 26, 2012 September 25 Field Trip To Deer Island}

Who: ERTG: Bottom, Hood, Jones, Krueger, Thom; Steering Committee: Doumbia, Ebberts, Krasnow, Studebaker, Zelinsky; Support Personnel: Johnson, Trask; Community Restoration Network (CRN): Cox, Deister, Gorman, Vlahakis; Others: Childs (Corps), McEwen (CLT), Sweet (BPA).

When: September 25, 2012, 1300-1700 h

Where: Deer Island, Oregon

\section{NOTES:}

- Toured Deer Island and examined areas proposed for restoration to familiarize the ERTG with the proposed action. Gorman (CRN) led the tour.

- Also visited the Columbia Stock Ranch (CSR), an adjacent property scored previously by the ERTG. McEwen explained plans for the CSR action.

\section{September 26 Meeting}

Who: ERTG: Bottom (phone), Hood, Jones (phone), Krueger, Thom; Steering Committee: Doumbia, Ebberts, Krasnow, Studebaker, Zelinsky; Support Personnel: Johnson, Trask; Community Restoration Network: Cox, Deister, Gorman, Vlahakis; Others: Connor (BPA).

When: September 26, 2012, 0900-1500 h

Where: PNNL Portland

Agenda:

1. Presentation and Question/Answer Session - Deer Island restoration action

2. Discussion - Application to ERTG work of findings in the 2012 Synthesis Memorandum and the ISAB's comments on the memo

3. Closed session - ERTG scoring for the Deer Island action

\section{NOTES:}

General

- Gorman et al. presented information on the Deer Island action. The ERTG had questions and comments which are documented below. The interaction and exchange among the ERTG, the Steering Committee, and the project sponsor (Community Restoration Network) was constructive and informative for all parties. CRN is a conservation and mitigation banking company whose 
mission is to work with property owners, agencies, tribes, and others to promote and enhance economic development and environmental health in the Pacific NW.

- Regarding application of the Synthesis Memorandum (SM) and ISAB comments to ERTG work, one area of interest could be the uncertainties in the knowledge base. The ERTG listed uncertainties from the perspective of scoring, whereas the SM authors addressed uncertainties concerning their four main questions (habitat use, factors limiting recovery, effectiveness of restoration actions, and estuary status). One prominent recommendation relevant to the ERTG is the need for improved understanding of the effectiveness of restoration actions. There is no need for the ERTG to revise the scoring criteria at this time.

- The discussion on ISAB comments diverged to how the ERTG accounts for indirect benefits from restoration actions to interior basin fish primarily migrating in the main stem. For example, is there an explicit way in the SBU process for ERTG to address the potential for material export? The weighting factors over-estimate density for stream-type fish, i.e., the process over-compensates the direct benefit to account for the indirect benefit.

- The ERTG completed scoring for Options 1 and 2 separately for the Deer Island action. They decided to present comments in a single narrative as opposed to individual comments by subaction by category (success, access, capacity). The intent is to improve the quality of the ERTG's feedback on a project by removing redundancy and being clearer and more explicit. This approach is consistent with the ERTG's approach to review projects from a holistic perspective.

\section{$\mathrm{Q} / \mathrm{A}$ on the Deer Island Action}

- Q: Why two options for restoration actions? A: There are two options because of concerns of the property owners. Option 1 covers a portion of the island because property owners want to preserve some of the existing land use and not give up the entire island. The signed lease between some of the land owners and $\mathrm{CRN}$ is for 1,000 acres, about $1 / 2$ the island. Option 2 is the full restoration project for the island. Negotiations are underway for Option 2.

- Q: Subaction 10.1 (dike breach) wetted area based on what elevation? A: 2-y flood, assumes the dike breaches result in complete hydrologic reconnection and inundation.

- Q: Why is there a notch in the setback levee for Option 1? A: Needed to get the total acreage to equal 1,000 acres so used this upland area to downsize the parcel.

- Q: In the northern part of the site where it borders the CSR parcel, and assuming CSR happens, will there be unrestricted access from the upland creeks through the two restoration sites to the main stem Columbia River? A: Yes, there will be open and free access from the creeks to the Col. R.

- Q: What's the bathymetry like in Deer Slough? A: Don't know exactly. Has likely filled in over the years. Probably has low slope.

- Q: How will the property owners access the ranch buildings under Option 2? A: The road along the dike; may need to build bridges or add culverts to cross some of the channels. Q: But if you breach the dike...? A: The plan is to build a bridge at the south end. There's a requirement to provide access to the Col. R. navigation aids.

- Q: Explain more about the flooding situation on the island. A: There will be multiple places where water will flow onto the island after breaching. Haven't done a hydrodynamic modeling to predict how much water and where. The plan is to breach areas along the slough, too, to increase circulation and inundation. 
- Q: What is the elevation of the interior part of the property where the cows were relative to the Col. R.? That is, will some of the interior channels become lakes instead of channels to the river? A: Not heard by the note taker.

- Q: The 2-year flood elevation was used to predict the wetted area on the site, but what do you think would happen on a daily basis in terms of inundation? A: Likely have water in the channels daily; this could be modeled.

- Q: Any existing data on water temperatures at various locations on the site? A: Water temperatures in the slough have been measured.

- Q: Some of the existing channels seem to have good riparian areas, but it looks like you're planning more riparian work based on the subaction maps in the project template. Please explain. A: In many places the riparian zone is reasonably thin. Plus the plan is to reforest to expand riparian areas to a $200 \mathrm{ft}$ buffer zone. Took a blanket approach on restoring riparian areas.

- Q: What was the plant community like before diking? A: Can examine the historical T-sheets to answer this.

- CRN Q: What's the ERTG's general guidance on revegetation? ERTG A: Go with native plants; choose the ones historically present to the extent this might be known; land elevation and hydrodynamics will be important controlling factors for plant development.

- Q: The internal remnant culverts may be significant; be sure to inventory and understand their impacts as they will affect the hydrology. A: Will do. Have a pretty good handle on the culverts, but will double-check to be sure.

- Q: Why put a breach in what appears to be a natural feature on the site, the linear berm along the western region of the island? A: The intent would be to provide access deeper into the site. Q: But the upland creeks will be reconnected to the slough and to the river though the CSR site. Seems like the site may be fairly well connected given the apparent inundation during the 1996 flood. A: Will reconsider this.

- Q: What about removing the levees Ducks Unlimited installed to make duck ponds? A: Not heard.

- ERTG Comment: Dike breaching in river systems is not just about tides and backwatering; it's also about overtopping banks. To have this, entire dikes must be removed, although it's understood that this is usually cost-prohibitive, and that river regulation has dampened episodic flooding.

- ERTG Comment: High energy flows entering the site at the upstream end of the sites will be important, maybe more so than backwater inundation from the breaches on the downstream end. Historically, flood energy likely came down through the site via Deer Slough (see the dendritic area in the northern part of the site). The sponsors are encouraged to continue considering the importance of energetic flooding.

- Q: How worthwhile might it be to remove even more of the outer dike? In Puget Sound, when dikes are breached entirely more tidal channels form than with partial breaches. A: Can consider expanding the breach at the southern end.

- Q: Vision statements provided are useful. Note, too, that restoration actions can contribute ecosystem services to the main stem, such as prey export that are likely important to interior basin ESA-listed salmon and steelhead.

- ERTG Comment: During the field trip, there was discussion of the possibility of reintroducing white-tailed deer to the island. It might not be a good idea to block off a portion of the island for 
deer. But, if there could be a situation where the salmon habitat restoration and deer management do not conflict, that's be good.

- ERTG Comment: This is a good project because of its size and location. However, need a better understanding of the details when they become available of how the system is expected to function after restoration versus how the system functioned historically. Based on experience sampliong fish in the Sauvie Island area, we need better understanding of bar and scroll habitat functions. Also, need better understanding of connectivity seasonally versus tidally.

- ERTG Comment: Concerned about breaching the apparently natural linear feature. Also, remove as many culverts as possible to improve hydrologic connectivity. In addition, look for other locations to improve availability and access for juvenile fish from the main stem.

- ERTG Comment: This is a very big project, but in some senses it's really an experiment. Think about the critical uncertainties to project success and have an adaptive management plan in place. CRN Reply: Recognize the need for hydrodynamic modeling. Just at the conceptual and preliminary design phase at this time. Understand that invasive species and revegetation success is an uncertainty. Intent is to convert reed canary grass areas to a woody system. Will be using the Ash Creek approach, like was done at Sandy River delta and Mirror Lake and revegetate all pasture areas. Plan to develop a long-term monitoring plan.

- Q: Water temperatures in the ponded shallow water areas are a major concern. Already know there are predators in these waters. How much the reconnections will reduce water temperatures is an uncertainty, as is the effects of non-native fishes on juvenile salmon at the site.

\section{B.2 ERTG/SC October 24, 2012}

\section{October 24 Morning}

What: Field trip to Dairy Creek/Surgeon Lake project

Who: Hood, Jones, Krueger (ERTG); Ebberts, Krasnow, Zelinsky (Steering Committee); and others

When: October 24, 2012, 0900-1200 h

Where: Sauvie Island, Oregon

\section{NOTES:}

- Visited the Dairy Creek/Sturgeon Lake project site on Sauvie Island, Oregon. The tour was led by Jim Adams, Corps project manager.

- Stops included Coon Point, Reeder Road Culverts, Jackson Lake/Sturgeon Lake fringe.

\section{October 24 Afternoon}

What: Presentation and questions/answers on the Dairy Creek/Surgeon Lake project

Who: Hood, Jones, Krueger (ERTG); Ebberts, Krasnow, Zelinsky (Steering Committee); Adams, Cisneros, Duffy, Thrush (Corps); Bennett, Dammarell, Wiseman (HDR); Springer (WMSWCD); Nedeker (ODFW Sauvie Island refuge); Trask (PCTA); Johnson (PNNL).

When: October 24, 2012, 1330-1600 h

Where: PNNL Portland

Purpose: Presentation and question/answer session on the proposed Dairy Creek/Surgeon Lake project 


\section{NOTES:}

- ODFW manages about one-half of Sauvie Island as a wildlife refuge.

- A monitoring plan with performance criteria will be developed to determine project action success.

- The Corps is concerned about sediment load from the Columbia River filling in Dairy Creek. The intent is that the refurbished Dairy Creek waterway between the Col R and Sturgeon Lake be selfmaintaining.

- Q: Expect erosion in the channel (Dairy Creek)? What's the water level of the Col R relative to the opening at Dairy Creek? Is Dairy Creek perched? A: Col R mean stage is $10 \mathrm{ft}$ and Dairy Creek is at $9 \mathrm{ft}$. A hydrologic reconnection is expected. ERTG Comment: It would be good to see a plot of mean [25 y] Col R stage over a year. Q: What's the historic elevation of Dairy Creek? A: Not sure. Do see some low spots on the old topographic maps.

- The group discussed the levee system and the delineations to determine project acreages. The Corps did not include all area within the $18.5 \mathrm{ft} 2-\mathrm{y}$ flood elevation.

- Q: Explain the duck management goal for the other wetted areas? A: Water levels are controlled to start the hunting program earlier in the season. Q: What would happen if the control structures were not in place? A: Areas would be dry for the most part. In the latest Sauvie Island management plan, ODFW's main focus is habitat for fish and wildlife.

- Q: How much deeper is Gilbert channel than the bottom of Sturgeon Lake? A: 10-15 ft. Q: How much water is exchanged between Gilbert channel and Sturgeon Lake? If Dairy Creek is restored, what would happen at Gilbert? What's the role of Gilbert channel in the system? A: Gilbert channel improves water circulation.

- Q: Is there tidal channel formation in the dendritic area where Dairy Creek enters Sturgeon Lake? A: Possibly.

- Q: How wide will the restored Dairy Creek be? The ERTG is concerned about the size of the channel relative to the size of the lake. A: To be determined. The creek is surrounded by private property but the land owners are supportive. Q: Won't the sharp turn in Dairy Creek affect flows? A: The turn is not artificial. The channel will need to be fine-tuned as part of the interactive design process.

- Q: How is opening Dairy Creek going to increase tidal prism? A: There will be more energy in and out of the area. Plan to study tidal exchange in a 2-D hydrodynamic model.

- Q: Sedimentation in the lake is an uncertainty. The documents suggested restoring Dairy Creek could increase scour in the lake, but shouldn't increased tidal exchange result in increased sedimentation? A: Col R has less sediment load now than historically.

- ERTG comment: It is a great idea to install a bridge over Dairy Creek to replace the dilapidated culverts.

- Q: The sponsors suggested that this could become a flow-through system when Dairy Creek is opened. It seems quite uncertain, however, what the circulation patterns will be. Comments? A: At times there will be a differential in elevation between the Col $\mathrm{R}$ and Sturgeon Lake. Flow through Dairy Creek will depend on this differential.

- ERTG comment: This project is going to be complicated and it will be difficult to predict what will actually happen. That said, it looks to have potential for positive benefits for juvenile salmonids. 
- Q: Can't really model which Dairy Creek channel would be best to improve, right? A: The 1993 Dairy Creek restoration seemed to result in braiding in Sturgeon Lake, with flows apparently going out through Gilbert channel.

- ERTG comment: There are a suite of hypotheses with this project, including a) net sediment loss, b) increase in braided channels, c) improved lake water quality, d) increase fish use of the lake, e) changes in vegetation zonation. These hypotheses will need to be tested with high quality RME.

- Q: What about the threat of colonization of the lake by piscivorous fish? A: It's possible.

- ERTG comment: A major uncertainty is how maintainable the Dairy Creek channel will be. Channels like this get blocked often.

- ERTG comment: Good potential for juvenile salmon prey-producing habitat. If so, should be supportive to fish.

- Q: Where's the chum salmon channel? A: Near Crane Slough, which is not connected to Sturgeon Lake.

- Q: Are there any other lake systems like this where there's data on sedimentation rates? Also, what's the source of the sediment? What is the contribution of the surrounding agricultural lands? A: There does not seem to be much sedimentation in Sturgeon Lake. Q: How about doing some sediment cores in the lake? A: Such work has been done in Vancouver Lake. May get some insights here. Also, HDR is examining sedimentation in Sturgeon Lake.

- Q: Already have fish access through Gilbert channel, and another access location would be established with the Dairy Creek restoration. But these provide only two entrances (and exits) to Sturgeon Lake. Comments? A: Additional entrances are being considered. Many factors are involved. The forthcoming feasibility study could address additional connections between Sturgeon Lake and the Col R.

\section{Closing and Next Steps}

- Johnson to send the presentation to Bottom and Thom, ERTG members who could not attend the field trip and meeting.

- ERTG to score the Dairy Creek/Surgeon Lake project during a conference call the first week of November 2012.

- After scoring, Johnson to prepare an SBU report for the project.

\section{B.3 ERTG/SC November 14 \& 15, 2012}

\section{November 14 Field Trips}

Purpose: Field trips to Gnat Creek, South Tongue Point, Colewort, Otter Point projects

Who: Bottom, Hood, Krueger, Thom (ERTG); Ebberts, Zelinsky (Steering Committee); and others

When: November 14, 2012, 1000-1700 h

Where: Greater Astoria area, Oregon

\section{NOTES:}

- CREST hosted tours of the four subject projects. All had been completed. 
- The ERTG toured Gnat Creek, South Tongue Point, Colewort for the purpose of scoring to assign SBUs.

- The group toured Otter Point to see the post-construction results; the project was scored in 2010.

\section{November 15 Meeting - Presentations and Questions/Answers}

Purpose: Presentation and questions/answers on the Gnat Creek, South Tongue Point, Colewort projects

Who: Bottom, Hood, Krueger, Thom (ERTG); Ebberts, Krasnow, Zelinsky (Steering Committee);

Doumbia, Karnezis, Read (BPA); Studebaker (Corps); Dalton, Geise, Lofman, Van Ess (CREST); Trask

(PCTA); Johnson (PNNL).

When: November 15, 2012, 0900-1200 h

Where: Cannery Pier Hotel, Astoria, Oregon

\section{NOTES}

\section{Gnat Creek}

- Madeline Dalton of CREST made the presentation.

- Zelinsky directed the ERTG to score only Phase 1, the 20 acre parcel that has been completed. For Phase 2, the 70 acre action under consideration, informal feedback would be sufficient at this time.

$\underline{\text { Phase } 1}$

- Q: How much subsidence has occurred? In the T-sheets, was the area higher than it is now? A: Do not know, but could look into this.

Phase 2

- The proposed action is intended to improve access for juvenile salmon, but there's currently available access routes. Comments? A: Currently, access is limited.

- Q: Is velocity really a barrier, especially since fish could enter on a flood tide? A: This is true, but high velocities could also reduce exploration of shallow peripheral habitats.

- Q: The more openings to a site, the better, but there must be diminishing returns. How many openings are necessary? A: Diminishing returns on the number of dike breaches is taken into consideration, especially given the costs of removing levee to create a breach.

- Comment: Maintaining the new breach openings is always an issue. Need energy. Much material is moved in large pulsed events, although consistent daily exchange is important, too.

- Q: The site is already wetted by the tides, right? A: Yes, there is a natural breach in the levee (50+ years ago).

- Comment: Need to consider material export from the site and effects of flood energy on the floodplain.

- Comment: The concept of "activating the area" is applicable here; the intent is to activate the area more fully than is presently the case.

- Comment: The ERTG struggles with the role of large woody debris in tidal restoration sites. There is uncertainty about how important it is functionally for fish.

\section{South Tongue Point}


- Sam Giese of CREST made the presentation. He noted that CREST desires feedback on these completed projects to apply to design of future projects.

- Q: Remarks on what seems like limited freshwater input to the site? A: Yes, freshwater input is limited to drainage through culverts and groundwater springs from the 95 acre basin above the site.

- Q: Historically, was there salmon spawning in the stream? A: pre-highway 30 and pre-railroad, there could have been.

- Q: Is it feasible to remove or rehabilitate the upstream barriers, e.g., the culverts? A: This wasn't included as a project goal because it is very time-consuming and uncertain to work with railroad and highway infrastructure.

- Q: How did the design for the 0.5 acres of channel come about? A: No reference area to work with, so we excavated to the freshwater input upstream. Q: The channel design is "iffy", although keeping the mouth at the new culvert open is what's most important. Comments? A: Expect daily tides (2X/day) will keep it open. Also, sand transport from the site should seal up areas near the mouth.

- Q: Which sedge species was seeded? A: It was a hydro-seed mix of salt grass, ledgey sedge, marsh clover, and others.

- Q: What are some typical salinity levels from the CMOP station at Tongue Point? A: Highs of 8-9 ppt in summer.

- Comment: The key is the channel design. The sponsor mentioned that passive design was not chosen because of concerns about having enough energy to form channel(s). The ERTG is concerned about whether the man-made channel will be self-maintaining. It is probably better to over-excavate the channel than under-excavate. Geise pointed out that the composition and cohesiveness of the material forming the channel wall and bottom is also important to selfmaintenance. TODO Ebberts to send Johnson to distribute to the parties the design document Williams and Associates prepared for channel excavations at Crims Island.

- Comment: Monitoring the channel cross-sections will provide key data on the effectiveness of this action and be very useful the adaptive management as new projects like this arise.

- Comment: Often folks try to do too much on a site; need to be careful and not over do it.

\section{Colewort}

- Madeline Dalton of CREST made the presentation.

- Comment: This will be an interesting project to learn from. The ERTG continually runs into the issue of large woody debris. We need data on its function for fish in tidal systems. Also, monitoring channel development will be useful to apply to design of future projects.

- Comment: The ERTG will discuss if removing material should be a Subaction 6.3 or other.

\section{Closing and Next Step}

- $\quad$ ERTG plans to score the Gnat, South Tongue Point, and Colewort projects on November 16, 2012. TODO After scoring, Johnson to prepare an SBU report for the project.

\section{November 15 Meeting - ERTG + Steering Committee}

Purpose: Coordination and discussion of ERTG business 
Who: Bottom, Hood, Krueger, Thom (ERTG); Ebberts, Krasnow, Zelinsky (Steering Committee); Doumbia, Karnezis, Read (BPA); Studebaker (Corps); Van Ess (CREST); Trask (PCTA); Johnson (PNNL).

When: November 15, 2012, 1300-1500 h

Where: Cannery Pier Hotel, Astoria, Oregon

\section{NOTES}

\section{Updates and Future Plans}

- All completed projects will be included in the 2013 Comprehensive Evaluation (CE) for BiOp reporting.

- AAs will include planned projects in the Implementation Plan (IP). Will have a mix of ERTG final SBUs, prelim ERTG SBUs, or prelim non-ERTG.

- $\quad$ AAs do CE and IP; finalize same time as BiOp -- CE is what AAs accomplished and how its affecting the listed stocks. IP is what's planned.

- $\quad$ NOAA does a response $=$ the new BiOp, judgment on whether the actions mitigate for effects of the FCRPS.

- DB: Interested in seeing the assessment. GH: Interested in the outcome of the process. Helps to know the big picture. TODO share the CE and IP w/ the ERTG when the AAs are ready.

- RT: How will the CE, IP, and BiOp be incorporated into the CEERP doc's? CS: CEERP covers more than the BiOp. Certainly they will inform the CEERP doc's. CEERP doc's explain the program. BDZ: also the CEERP will inform the CE and IP.

- LK: In the BiOp, we don't emphasize how much FCRPS flows affect the estuary and its value to interior species and lower river fish.

- $\quad$ BiOp due end of 2013. Public draft 9/30/12.

- GEJ: new types of projects for 2013? BDE: yes, habitat creation project. Have a team working on designs now. Habitat creation is another approach in the toolbox. BDZ: May also put forth a pile structure project.

- BDZ: Upcoming work products. For example, landscape planning framework, three tiers of EP, etc. may be worth having feed back from the ERTG. Planning to ask the ERTG for comments because want to true them up, but also apply to ERTG's work if appropriate.

- RT: What is the definition of a final score? GH: Maybe have an as-built score. Then 5-10 yrs later, do a "final" score. BDZ: Score a 60-90\% design, which is the final unless the construction is very different, so can ask the ERTG to score again. The post-construction 5-10 yrs is problematic because of the BiOp process; can't change SBUs. But, still want to learn to improve things. RT: This is where the CEERP program comes in and its AEMR. CEERP May help the case that even w/ SBUs still trying to see if things are working. BDZ: We support adaptive management (AM) completely, whether it's CEERP or BiOp or whatever. BDZ: Colewort and Kandoll are two examples of AM where original work needed to be modified.

- TODO Johnson to send LOE (Diefenderfer et al. 2012) to ERTG for their info'.

\section{ERTG+SC Discussion -- Water Surface Elevation -- ERTG Doc\# 2012-01}

- ERTG has revised the document based on SC comments. The ERTG is good to go. 
- TODO Johnson to send ERTG 2012-01 to the SC. TODO SC to perform final review.

- RT explains the doc. 2-y flood event everywhere is above EHW in tidal portion, but ERTG reserves right to incorporate EHW on a site by site basis after examining site characteristics.

- PCT: EHHW higher than 2-y flood elevation in tidal areas.

- RT: Using EHW from NOAA tide graphs; can't get EHHW. This is essentially the same as EHHW.

- BDZ: What are the attributes of a project that would lend themselves to using EHW instead of 2-y flood? RT: It's a vegetation concern, e.g., if the wetted area ends up including a dry upland, that's no good. Essential it's a QA/QC step by the ERTG.

\section{Closing and Next Steps}

- The ERTG will work on an approach to scoring floodplain lake reconnection actions.

- The next ERTG meeting will be a regional event, December 12, 2012 at NPCC in Portland, OR.

\section{B.4 ERTG/SC December 11, 2012}

\section{December 11 Field Trip}

Purpose: Field trip to the Wapato Access project site

Who: Hood, Krueger, Thom (ERTG); Ebberts, Zelinsky (Steering Committee); Corbett, Johnson M, Kolp (LCEP); Johnson G.

When: December 11, 2012, 1000-1200 h

Where: Sauvie Island, Oregon

\section{NOTES:}

- LCEP hosted a tour of the subject project. The design phase has been completed. The project is scheduled for construction in summer 2013.

- The ERTG toured the site for the eventual purpose of scoring to assign SBUs.

\section{December 11 Meeting - Presentations and Questions/Answers}

Purpose: Presentation and questions/answers on the Wapato and Honeyman projects

Who: Bottom, Hood, Jones (phone), Krueger, Thom (ERTG); Ebberts, Zelinsky (Steering Committee); Bennett, Corbett, Johnson M, Kolp (LCEP); St. Pierre (Scappoose Bay Watershed Council); Trask (PCTA); Johnson G (PNNL).

When: December 11, 2012, 1400-1600 h

Where: PNNL, Portland, Oregon

\section{NOTES}

\section{Wapato}

- Marshall Johnson of the Lower Columbia Estuary Partnership made the presentation.

- Q: What is the explanation for the two 2-y flood elevations? A: The water surface elevation at 19.0 $\mathrm{ft}$ is per ERTG guidance (Doc\# 2012-01). The other elevation at $17.3 \mathrm{ft}$ is from previous work by 
the LCEP before the ERTG guidance was released. The acreages in the project template used the $17.3 \mathrm{ft}$ elevation. TODO LCEP to update the subaction acreages to reflect the $19.0 \mathrm{ft}$ elevation.

- Q: How does the $19.0 \mathrm{ft}$ elevation relate to the vegetation on the site? A: At this elevation, reed canary grass is transitioning to upland forest.

- Q: Engineering drawings for the channel? A: See the drawings in the proposal package.

- Q: Will the bottom of the channel be lined? A: Yes, with cobble.

- Q: What is the available fish data from Multnomah Channel? A: Talked with Murtaugh, ODFW biologist. Also have information from Teel et al. (2009) on genetics at the Smith and Bybee lakes near the confluence of the Willamette and Columbia rivers. [Note, we learned the next day that Bottom et al. recently have been sampling sites in Multnomah Channel; LCEP might consider contacting Bottom.]

- Q: What are the temperature conditions in the existing wetland? A: During 2012, temperature above $21 \mathrm{deg} \mathrm{C}$ were not recorded until September, except for one isolated peak August 16-18, 2012 when temperature ranged between 21.0 and $22.2 \mathrm{deg}$ C. Q: Any other water quality data or comments? A: One observation is that conditions in the system are cyclical. Also, these systems seem to respond to water surface elevation in Multnomah Channel even though they are behind a natural levee.

- Q: Do you have any examples of scrape-down like is being proposed here to learn from? A: There are lots of examples but actions and results depend on specific project goals, hydrology, and site conditions. We are targeting an elevation where reed canary grass is not found.

- Q: Concerned about fish stranding when the water surface elevation drops. Comments? A: At other sites, such as Campbell Lake in Reach F in Oregon, we did not find juvenile salmon present in the summer. Ebberts added that researchers at Tenasillahe Island observed fish over-wintering in a tidal slough behind a tide gate.

- Q: Why was the $14 \mathrm{ft}$ elevation chosen for the channel invert? A: The goal of the project is to correct for impacts to hydrology at the site caused by water flow regulation by the hydrosystem. But, while the intent is to restore site hydrology with the new channel, there is concern about impacts to existing plant and animal resources at the site. Also, if the water level goes too low, there would be an aesthetic concern. There is a relatively large amount of acreage at the site in the elevation range 13.0-13.5 ft. A 14-ft elevation preserves this while providing about 6 week additional inundation when water is above $14 \mathrm{ft}$. The stakeholder were not supportive of an elevation below $14 \mathrm{ft}$.

- Q: Historically were there channels connecting the site to Multnomah Channel? A: Haven't noticed any in the historical maps. High river flows over-topping the natural levee apparently provided the primary connection.

- Q: Project goals? A: Primary goal is to restore historic hydrology as much as possible. Secondary goal is to enhance habitat.

\section{Honeyman}

- Janelle St. Pierre of the Scappoose Bay Watershed Council made the presentation. This project has already been constructed. The ERTG did not do a field trip to the site because it is presently inundated. 
- Q: Is there a tidal signature at the site? A: Yes, 2-3 ft. It's especially noticeable when the Columbia and Willamette rivers are not high.

- Q: What is the distance from the main stem Columbia River? A: $\sim 5$ river miles.

- Q: At flood stages, are the fish from the main stem Columbia at the site? A: Yes, the floods provide good access, especially with the extensive network of wetland channels.

- Q: Is fish stranding or trapping a problem when water surface elevations drop? A: No, there are many water pathways out of the area. Also, in Scappoose Creek downstream in the system, there is always water. It takes time for the Honeyman site to drain out.

- Q: What is the primary vegetation in the area? A: Reed canary grass.

- Q: Channel cross-sections or shapes? A: Narrow and straight in some areas; broad and gradual in others.

- Q: In the template, you noted that insects are not a limiting factor. Further comments? A: Work by CREST in Scappoose Bay showed there were lots of diptera.

- Q: Width at the bridge crossings? A: $1.5 \mathrm{X}$ channel width.

\section{Closing and Next Steps}

- The ERTG will score the Wapato and Honeyman projects as soon as possible.

\section{B.5 ERTG/SC February 19, 2013}

Who: Bottom, Ebberts, Hood, Johnson, Jones, Krasnow, Krueger, Studebaker, Thom, Trask, Zelinsky

When: $2 / 19 / 13,1300-1420 \mathrm{~h}$

Where: Telecon

Why: Discuss the ERTG's draft approach for scoring floodplain lake reconnection actions

Notes:

- The ERTG is still working on a write-up of the subject approach. Should be finished w/ a draft by March 1 to send to the Steering Comm.

- ERTG explained their approach: conceptual model, fish densities and weighting factors, effective wetted area, accounting for existing access (see notes that follow).

- A conceptual diagram has been developed. Identified info' needs, e.g., mean fish density in floodplain lakes.

- Fish density and distribution are a concern. Struggled to find info'. Did find some literature values. Decided to choose conservative density, but apply it over the total wetted area of the lake, i.e., no edge zone designated.

- Floodplain lake test cases - ERTG performed initial scoring for Wapato and Dairy Ck/Sturgeon Lk.

- Yolo Bypass in central CA (Sacramento R) is a floodplain bypass for juvenile salmon. Has some good fish density data, but not exactly comparable w/ LCRE. Also looked at OR coastal lakes and other LCRE floodplain lakes.

- Value to stream-type fish from floodplain lake reconnn? Yearling coho known to use Smith and Bybee and Lewis R (C. Baker's work). 
- Likely will need a case by case analysis. May also need mngt actions to ensure maintenance.

- Subaction 10.2. Most approp. subaction given the subactions available. Will have a special weighting factor for floodplain lakes. Optimal density $=0.005 \mathrm{fish} / \mathrm{m} 2$. Weighting factor $=0.556$.

- May need to establish a definition for floodplain lakes. There are lakes, ponds, wetlands, etc. What is a "floodplain lake?" There are lots of hybrids.

- Will need to define when the subaction 10.2 floodplain lake situation would be applicable.

- Given existing access (e.g., Gilbert at Sturgeon), the ERTG down graded the scores for capacity and access.

- Test scores for the Wapato and Dairy Ck/Sturgeon Lk actions? ERTG concerned about access. Water temperature may be a problem. Will present the project scores after final review by ERTG.

- Also depends on the historical hydrologic connection. Degree of access depends on how it functioned in the past. Is a natural process being restored? For many of the floodplain, the dominant forming process was large floods which do not occur like in the past.

- ERTG scoring on certainty of success, access, and capacity for these types of actions.

- How did ERTG treat export of prey/detritus? Reviewed the lit. Included this topic in the write-up. Thought it was comparable to other wetlands.

- Did the ERTG examine the Willamette R gravel pits? No, but are there fish data?

- AAs will take ERTG's input on floodplain lakes and decide what to do in the future for BiOp implementation.

- Lots of uncertainty in knowledge base of juvenile salmon ecology in floodplain lakes. There's no quick and easy answer.

- ERTG will be providing guidance to sponsors in terms of important information to include in future project templates. Address issues as approp. that the ERTG raises. Each lake will be unique.

- Historical processes that formed the lakes and allowed fish access are different than contemporary processes because of flow regulation, diking, and others actions.

- $\quad$ Path forward =

- 2/20 Initial, unofficial scores/SBUs with new weighting factors and guidance for wetted area for Wapato and Dairy $\mathrm{Ck}$ to SC

- 2/21 Greg sends complete draft write-up

- $2 / 250900 \mathrm{~h}$ ERTG call to finish the write-up

- 3/1 Finish draft write-up and initial test scores w/ comments for Wapato and Dairy; send to $\mathrm{SC}$

- 3/5 $1500 \mathrm{~h}$ ERTG+SC call to discuss

- 3/8 Finalize ERTG work product on floodplain lakes

- March meeting -- March 18 and 19 in Portland.

\section{B.6 ERTG/SC March 18 \& 19, 2013}

\section{March 18, 2013}


Field trips to Dibblee Pt, Post Office Lake, and Oaks Bottom

Who: Bottom, Thom, Krueger, Hood and others.

\section{March 19, 2013}

Who: Bottom, Thom, Krueger, Trask (PCTA), Tom Josephson (CREST), Studebaker, Barbara Cisneros (Corps), Jim Adams (Corps); POL only = Brian Zabel (Corps); Oaks only = Mellisa Brown (City of Portland), Sean Bistoff (Portland), Paul Cetcham (Portland)

When: March 19, 2013, 0900-1600 h

Where: PNNL Portland

Why: Project presentations and ERTG+SC discussion

\section{Project Presentations}

Dibblee Pt -- Josephson (CREST)

- Q: Is the site still used for dredge material disposal? A: Dibblee Pt is currently being used as a staging yard to sort and sell material. There is no net accumulation of material. Q: What about the material they don't sell? A: Mostly sell the sand fairly quickly, but eventually sell all of it.

- Q: Edges of the bay are highly vegetated. Is it filling in? Seems like a critical element is to maintain the connection through the bay between the site and the main stem river. A: The bay is probably not filling in. At least it's not noticeable because it's stayed in the particular shape for $50 \mathrm{y}$ or so.

- Q: Dibblee Pt seems pretty stable, right? A: Yes, maintained unchanged for $50 \mathrm{y}$.

- Q: To maintain the channel, need enough energy in and out. Confidence in this? A: The channel was engineered such that volume of water behind the channel was purposefully underestimated to be conservative.

- Q: New culverts are usually $1.5 X$ stream width, although this is not a natural stream. This culvert is somewhat "pinched." Comments? A: 1.5X more applicable for systems higher up in watersheds with flashy flows. Channel does go from stream width of $20 \mathrm{ft}$ to $14 \mathrm{ft}$ in the culvert. It would not have been possible with given funding to do a $20 \mathrm{ft}$ culvert.

- Comment: Some concern about "created" habitat. Another concern is structures.

- Comment: In a dead-end bay, need to keep the channel open. Too wide, not enough scouring E; too narrow, too much scouring.

- Q: How much of the bay drains on the average tide? Also, is the pond behind the culvert dry at low tide? A: At lowest low tide still have about $2 \mathrm{ft}$ water in pond.

- Q: How long will the pond-like feature persist? Tides will bring in sediments that will settle out. A: But, on the other hand, flows out of the area could be higher, therefore suspending and removing sediment. Comment: Would be good to see if the pond is filling. Maybe use scour pins (a kind of sediment accretion stake).

- Q: Explain the thinking behind the choice of subactions? A: Sub 1.4 riparian channel improvement. Sub 9.4 Strictly the channel work. Sub 10.1 removal of the berm. Sub 10.2 is the reconnection with the $14 \mathrm{ft}$ culvert opening area behind it.

Post Office Lake -- Jim Adams (Corps) 
- [channel elev. peak at $9 \mathrm{ft}$ NAVD88 (same as Dairy Ck; levee notch at el $18.7 \mathrm{ft}$.]

- [Corps is working w/ NMFS on a BiOp for the project.]

- Q: What's the elevation of the natural levee compared to the one on the other side of the river (Sauvie Is)? A: Existing sill is at el. 19-23 ft NAVD88.

- Q: Will the plug in the channel stay (el. $9 \mathrm{ft})$ ? A: Naturally occurring feature in the channel. Leaving in, in part due to request from USFWS to maintain water in POL for birds.

- Q: Will Round Lake on the Fazio property $\mathrm{u} / \mathrm{s}$ have water in it in the summer? A: Yes.

- Q: Why is Dusky Lake being included in the subaction acreage? A: Fish can access Dusky over the stop log structure during higher winter flows (above 16-17 ft). Q: When water does flood over berm, the stop logs are not in, right? A: No, they probably are in. NMFS and USFWS are concerned about stranding in Dusky Lake. There likely will be a change in management of Dusky Lake depending on the $\mathrm{BiOp}$ results. Working w/ NMFS to establish an adaptive management plan and a monitoring plan to operate the stop log structure for Dusky Lake.

- Q: What's the status of the Fazio project? A: The Fazios are working w/ NMFS on permitting. Q: Are the two projects (POL and Fazio) dependent on each other? A: No, but the designs are being informed by one another.

- Q: Is the bank project being presented to NMFS as connecting to POL? A: Yes. Jeff Fisher at NMFS wants to connect the Vancouver lowlands. Regulatory component for Corps for the Fazio project is covered by the Seattle District.

- Q: Tell us more about the deep water pool refugia? A: NMFS supports pocket pools. Could be good as temperature refugia and help reduce stranding. Will include root wads for cover. However, others are concerned about creating predator habitats.

- Q: Monitoring plan? A: Working on it w/ USFWS and others. Want to monitoring X-sec and bathymetry. Q: Monitoring predation? A: Not proposing to do this at this time. Depends on funding.

- Q: What predator species have they found in Campbell Lake? A: See the new report from EP.

Oaks Bottom -- Jim Adams (Corps)

- [Culvert $16 \mathrm{ft} \mathrm{W}$ x $12 \mathrm{ft} \mathrm{H}$.]

- Q: Area with the house boats is natural? A: All Oaks Bottom was floodplain wetland habitat connected to the river. Oaks was going to be filled completely but was saved in 1970s to be a wildlife area. Note, there is clear clean ground water flowing into the system.

- Q: Why the weirs? A: Prevent head cutting of the channel. Agreements in place w/ others. Highest elevation ensures a minimum 4 acre water feature, but when fully inundated could be a large as 60 acres.

- Q: Vegetation? A: Have a reveg' plan from 2010 (will be updating this). Comment: Suggest considering slough sedge and spike rush.

- Comment: the riparian part of this huge. Good to include plants that can out-compete RCG. A: Yes. Note riparian work expressed as acreage and converting to linear miles will underestimate the contribution to the ecosystem. 
- Q: Is there a monitoring plan? A: Yes, there's a draft. Very much interested in effectiveness monitoring, e.g., want to know which reveg'strategies are most effective.

- Q: What about beaver management? A: Want the beavers there. But will take an AM approach. Don't want the beavers to make a dam that blocks fish passage. There is a "beaver deceiver" on site, but it's very labor intensive to maintain. Will examine how beaver activity relates to the design objectives of the project. Want beaver to be part of the ecological process.

- Q: Railroad line? A: Private spur line operated to move refrigerated freezer cars through the site. Will have to do an open cut to replace the culvert; no way around it. Currently planning to provide a temporary bridge on weekends for the rail cars to move back and forth.

- Comment: Images of potential restoration results can have a big impact.

- Q: How far is the project from Col R.? A: 16 miles.

- Q: Does the monitoring include fish? Turtles? A: Yes. No salmon can access the area under preproject conditions. Will be monitoring fish species over time, among other indicators. City has instituted a long-term monitoring program modeled after EMAP.

- Comment: Would be good to have Chinook salmon genetic data from the area.

- Comment: Also consider export of prey and macro-detritus.

- Additional items to provide the ERTG: reveg' plan, Mon plan, Melissa's images . (Send to Ebberts to send to Johnson to send to the ERTG.)

\section{ERTG+SC Discussion}

Who: Bottom, Doumbia, Ebberts, Hood, Johnson, Krueger, Read, Studebaker, Thom, Trask.

Floodplain Lake Reconn -- ERTG Doc\# 2013-01 Draft

- BDE -- Note that the Action Agencies reserve the right to reconfigure or otherwise change the existing project proposals (e.g., Dairy Creek/Sturgeon Lake) depending on the outcome of the ERTG's work on the approach to assigning SBUs to floodplain lake (FPL) reconnection projects.

- ERTG provided a recap of the approach. See the conceptual model. Lots of uncertainty. Not much data on fish use, especially fish density data in FPLs. The ERTG chose a conservative density. But still believe there is a potential for useful habitat. Each FPL is unique. One of main functions could be the export of materials. An uncertainty is the predation potential. ERTG was conservative because of the uncertainty.

- Q: In their literature review, did the ERTG screen out studies that didn't provide a density estimate? ERTG: Yes, must have density data to understand production potential and inform the SBU weighting factor. Also, growth rate data would be useful to demonstrate ecological benefit.

- Q: Why a new weighting factor? Why not just use an existing subaction and its weighting factor? ERTG: Lakes are unique relative to what the ERTG has been given before. Also, ERTG considered establishing a new subaction for FPL reconnections, but that would have been problematic. Therefore, the ERTG used existing data from other FPL systems and built a new weighting factor for the module subaction 10 series (hydrologic reconnections).

- Q: What about a project where FPL is connected w/ a dike breach, which would not be a subaction 10.2 as outlined in the Doc\#2013-01? ERTG: Would need to consider this. 
- The Corps provided a handout on the effects of using subaction 10.1 vs 10.2 vs 10.3 for a given project and scores. Note the effects of the ERTG's conservatism. For example, there appears to be a discrepancy between how ERTG is examining levee breach vs culvert removal. The Corps requested that the ERTG consider this information as they formulate the approach to assigning SBUs to FPL reconnection projects.

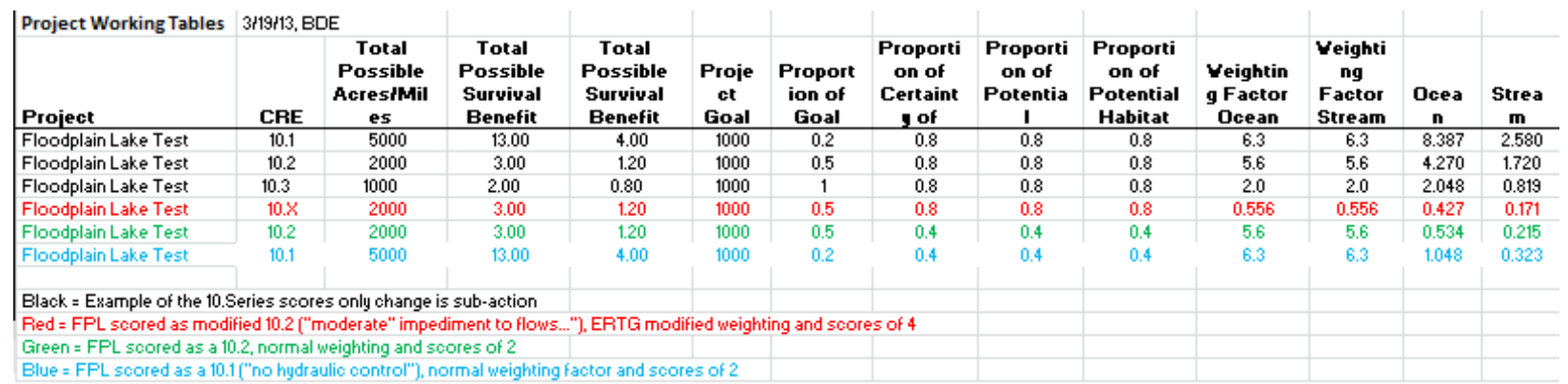

- ERTG: Admittedly the process is ad hoc. The ERTG tries to find solutions to the problems they're given. FPLs are one of these situations.

- Corps: Also, seems like FPL got dinged twice -- once for the new, lower FPL weighting factor and another instance for lower scoring in the face of uncertainty. ERTG: To clarify, the ERTG adjusted scores downward to account for existing access and uncertainty.

- Note: In Doc\#2013-01, clarify that projects will be scored on a project-specific basis, i.e., the approach is not set in stone and can be adjusted based on project conditions.

- Corps: AAs use cost per SBU to decide on projects.

- Q: Consider POL in deliberating about the FPL approach. Subactions? Weighting factors? ERTG: Might keep same weighting factor but change the subaction, although this is TBD.

- Q: What really is a FPL as opposed to a wetland? ERTG: They all blend in some respects. How to deal $\mathrm{w} /$ variability in ecosystems is difficult.

- Q: If see channel features indicating tidal influence, does this imply wetlands? ERTG: Yes, but also consider the vegetation. Try to understand what fish can get out the habitat.

- Q: Is a distinction whether it's seasonally inundated? ERTG: Makes sense.

- ERTG: In adaptive mngt under CEERP, the implication is to resolve the uncertainty about fish densities in FPLs.

- Q: Consider adjustment to stream-type SBUs because of export fro FPLs? ERTG: Need the information to change from the "existing method." ERTG necessarily is conservative.

- [Use experience w/ POL as a FPL when finalizing ERTG Doc\#2013-01.]

- [ERTG to review the Belmore paper that Ron sent.]

- Conclusions on things to consider changing in Doc\#2013-01:

$\circ$ Explain the conditions where the $10.2 \mathrm{FPL}$ w/ weighting 0.556 apply

- Temper language on use of $10.2 \ldots$ not mandatory

\section{Next steps:}

- March 25 COB -- General issues and comments on Doc\#2013-01 due to Johnson to forward to the ERTG. 
- March 26 1300-1600 h -- ERTG-only conference call to: A) Score POL (trial), Dibblee, and Oaks. B) Revise FPL Doc\#2013-01 based on Steering Committee comments and the experience of assigning trial SBUs for Dairy Creek/Sturgeon Lake, Wapato, and Post Office Lake. (Note: preliminary or final SBUs for these projects cannot be assigned until the ERTG approach for FPL reconnections is finalized.)

- April 16-18 -- ERTG event TBD.

\section{B.7 ERTG/SC April 16-18, 2013}

\section{April 16, 2013 - ERTG+SC Discussions and Project Presentations}

\section{Agenda}

ERTG+SC discussions

- Updates

- FPL approach

- FPL workshop

- Dibblee subaction(s)

Presentations

- $\quad$ North Unit

- Sandy R Delta Dam Removal

Scoring (ERTG only)

- Dibblee Point

- Post Office Lake

Who: Hood, Jones (phone), Krueger (phone), Thom, Doumbia, Ebberts, Johnson, Krasnow, Roberts (BPA), Trask, Zelinsky

Where: PNNL Portland

\section{Updates}

- Puget Sound Institute - The PSI is convening a workshop on large scale ecosystem restoration to gather lessons learned from estuaries around the nation (Everglades, Chesapeake, LCRE, SF, etc.). Information transfer is important, but hard to do. This is an opportunity to communicate the LCRE restoration work to interested parties nationwide. Ron Thom is on the executive committee. There will be contribution on lessons learned from the LCRE; details TBD.

- $\quad$ BiOp -- Remanded BiOp means AAs submit a CE and IP (Implementation Plan). BiOp Comprehensive Evaluation (CE) is moving from AAs to NMFS. Includes a projection of what can be done at program level. Want to have ideas of the projects to implement in the future. Use the $\mathrm{CE}$ as a description of the program's success. The IP is the plan for going forward. The AAs submit the CE and IP to NMFS for NMFS to write the BiOp. BiOp due to Court 12/31/13. A draft will be released (limited) this summer. What will happen after 2018? What will the emphasis on the LCRE be? We'll see; TBD. 
- Time constraints for ERTG work -- ERTG needs to 1) assign SBUs for the projects that they've done or are upcoming, and 2) provide info' for the AAs to develop IP. Work from ERTG needed by this summer.

- Outreach -- Consider sharing adaptive management learning between trib's and LCRE. Joe Connor from BPA would be interested in facilitating a meeting w/ Upper Col Technical Team. Follow up TBD.

\section{ERTG+SC Discussion -- FPL Approach}

- $\quad$ SC -- How to identify a "great" FPL project even in light of uncertainty and given the weighting factor for FPL? What's the approach to move forward? ERTG A: Projects that we thought were not that great had limited access and egress (e.g., Wapato). Dairy Ck/Sturgeon was a concern bec of self-maintenance issue, constrained access, and presence of Gilbert Ck. A "great" project would likely involve more breaching.

- $\quad \mathrm{SC}$-- If have large breach reconnection, would it not be a floodplain wetland and not a lake? A: Not nec. Depends on the definition.

- $\mathrm{SC}$-- But the weighting factor affects everything even if it's scored at 5. What to do in light of this? Are there other "levers?" A: One lever is the subaction chosen.

- ERTG -- ERTG struggling w/ fact that FPLs can be huge areas so need to be careful. Also, the actions won't ever recreate the historical pulsed flood events because of hydro regulation.

- ERTG - Weighting factor is based on best data available on fish densities in these types of systems. Can be changed as new data become available. Weighting factor doesn't inhibit SBUs. Get casespecific data on fish densities (salmon and resident fish).

- SC -- Will bring some more FPLs at least for prelim scoring. ERTG -- Need to learn from these types of projects. Could improve the scores if the positive attributes are emphasized.

- $\quad \mathrm{SC}$-- AAs and NMFS working on remanded BiOp -- avoid jeopardizing continued existence of the listed stocks. How to deal w/ scoring for stream-type fish? Would export from FPL to main stem been important here? Provoke discussion. ERTG -- would need to think about this.

- SC -- Maybe NOAA Restoration Center could fund a FPL restoration and AAs fund RME to learn.

- SC -- Definition of a floodplain lake? A: ERTG did not define FPL. SC: See definition in Steigerwald presentation (tomorrow).

- $\quad$ ERTG -- FPLs may be a 10.1, 10.2, or 10.3. SC-- But weighting factor is for 10.2. What about the weighting factor for a FPL that the ERT may use a subaction 10.1 or 10.3 on? ERTG -- Need to think about this. Could have different weighting factors for 101., 10.2, and 10.3.

- TODO GEJ to forward the latest ERTG version of Doc\#2013-01.

- Path forward re: Doc\#2013-01? Option A -- Finalize for now, then change if nec. Option B -Finalize after the wkshp. The ERTG+SC decided on Option B.

\section{ERTG+SC Discussion -- FPL Workshop}

- A new workshop is being organized by EP (Corbett). Convened a steering committee to develop it. Focus on discussions and learning that perhaps the ERTG hasn't seen. Help address the uncertainties.

- $\mathrm{GH}$ - Consider inviting Dan Schindler (UW). Lake ecologist. 
- $\quad$ ERTG -- Had talked about a workshop for this very purpose. Make sure the speakers understand the ERTG's uncertainties, scoring, FPL approach, etc.

- Add an ERTG member to the FPL steering comm. Ron volunteered.

- Workshop -- 1-d the week of June 17, coinciding with the June 2013 ERTG event.

\section{ERTG+SC Discussion -- Dibblee Subaction(s)}

- During review of the Dibblee project, ERTG thought the sponsors should consider whether to use Subaction 6.2 (beneficial use of dredged material) instead of Subactions 9.4 and 10 series.

- PT -- Original intent of subaction 6 was placement of dredged material.

- SC -- Trying to score the functional effect, not the action. ERTG doesn't distinguish by type of substrate. Using the 6 series may be problematic. Material as been there for at least $30 \mathrm{y}$.

- $\quad$ ERTG -- Difficult to apply a first-principle response of self-maintenance, natural control to a subaction 6.2.

- $\quad$ ERTG -- Didn't want to miss opportunity for a subaction 6 series if it was approp. Keep originallyproposed subactions for the project because of the current status. ERTG agrees.

- $\mathrm{SC}$-- Some projects in pipeline may be Subaction 6.

- SC -- Goat Island built from dredge material. Good habitat. Represents a trajectory of a habitat creation project. If put material in right location, can get positive trajectory to produce good fish habitat.

- JD -- CRT modeling (Delph 3D) for the LCRE; identifying areas of erosion and accretion. Might be useful for deciding where to place dredge material (habitat creation).

\section{Presentation -- North Unit}

Presenters: Tom Josephson (CREST) and Allan Whiting (PCTA)

Notes:

- Q: What's the historic pattern of flows thru Ruby complex? A: Nominal tidal channel thru Cunningham Slough. Cunningham slough is largely tidal. Dominate drainage feature is still Cunningham Slough.

- Q: ERTG to score Phases 1, 2, and 3? A: just Ph 1 and 2. Q: Is Ph 2 contingent on completing Ph 1? A: No.

- Q: How did the sloughs form in the high elevation splays? A: The sloughs are actually part of the splay-formation process.

- Comment: Splays form bec of a natural river levee that gets breached in a flood flow. The invert of the channel of the crevasse splay is higher than normal flow of river. Access for fish at high flows is good.

- Q: History of the site? A: ODFW managed. Q: How did RCG get established? Farmed previously? A: Yes farmed.

- Q: Water control structures did not work to prevent RCG, right? A: Yes, not enough flooding in early part of year when flooding can impact RCG. 
- Q: What were the manager's fish objectives (ODFW)? A: NMFS originally permitted the water control structures. Q: Also, ODFW has Mngt Plan for Sauvie and the water control structures are not part of the vision for the future.? A: Yes.

- Q: Managing for water fowl or fish? A: More fish in NU; water fowl a higher priority elsewhere on the island. Q: Has the conflict over birds vs fish been resolved here? A: Yes, ODFW is engaged and NU is not being managed for birds. But, the intent of the project is to not make things worse for the ducks. BDZ - from programmatic point of view, may do more work to identify failed water control structures and remove them to benefit fish.

- Q: Where will the soil from the scrape down be deposited? A: Most will be trucked to pasture near the parking lot and placed there.

- Q: If this is an experimental site, is there a risk folks will back-track on commitment to fish and go back to ducks? A: ODFW moving emphasis on ducks to areas elsewhere on the island. No indication ODFW would want to go back to managing using water control structures.

- Q: Will all hard structures be removed? A: Yes, including the water control structures and the associated riprap.

- Q: There are a lot of lakes in this area. Not FPLs? A: Vegetation is not lake-like. Another aspect is the channels that are there year-round, but not the wetlands ponds and lakes. Q: Maybe when flows were higher and unregulated, they were lakes.

- Q: Will the steps be disconnected from the outlets at low water? A: No.

- Q: What's known about water temperatures? A: Have probes in the water. Hope the data show same temp's onsite as main stem Col R during higher water. During low water, may be warmer. However, don't know if temp's are a limiting factor.

- Q: Is there a tidal influence to water temp? A: Don't know.

\section{Presentation -- Sandy R Delta Dam Removal}

Presenter: Michele Rhodes (Corps)

Notes:

- Q: How much of the dam will be removed? A: All of it. Q: How much will the channel be widened? A: Some but won't go the historical widths. Will excavate "pilot" channel to maintain flows year round.

- Q: Could potentially have an evulsion to take river back to more historical conditions? A: Yes, very well could.

- Q: Expect bed load from Sandy to move down this channel or the west channel? With Marmot Dam in Sandy removed, could expect big bed load flows. Would these go down the east channel? Might the channel fill up with gravel? A: Purpose of pilot channel is to get things started (digging down to invert elevation of Col at outlet) and let the river evolve naturally.

- Q: Why did the channel outside Sun Dial fill in? A: Don't know.

- Q: What's going on $\mathrm{w} /$ the riparian plantings? A: Planting upland plants in 1 acre total along north shore of channel. 
- Q: How much is the channel flow out of the Sandy? How much is flooded when the Col R is at 50\% excedance? A: See 10.1 map. Q: Key question is what is the difference in flooding before and after the dam removal? Want the channel to be connected to Col $\mathrm{R}$ all the time? A: Yes.

- Q: Any concerns the channel will fill in and become blocked? A: Talked about this. Will monitor to see if there is fish stranding; if so, will clear the blockage. Expect much more normal hydrologic conditions.

- Q: Is this project part of City of Portland's HCP? A: Yes.

- Q: How wide will the pilot channel be? A: Bottom width $=20 \mathrm{ft}$. Top width $=60 \mathrm{ft}$. Depth will vary depending on existing ground surface. Q: Is the channel going to allow flow down the from the Sandy, i.e., will flow from Sandy diverge into the channel? A: Yes.

\section{Scoring (ERTG only)}

- The ERTG scored Dibblee Point and Post Office Lake (POL). POL is a "test" score pending finalization of the approach to assign SBUs for floodplain lake reconnections.

\section{April 17, 2013 - Field Trips and Project Presentation}

\section{Agenda}

- Field trips to Louisiana Swamp (near Westport Slough, Oregon) and North Unit (Sauvie Island)

- Presentation -- LA Swamp

\section{Field trip to Louisiana Swamp}

Who: Hood, Jones, Thom, Bennett, Collins, Corbett, Doumbia, Ebberts, Johnson, Joki, Roberts, Zelinsky

\section{Field trip to North Unit}

Who: Hood, Jones, Thom, Bennett, Collins, Corbett, Doumbia, Ebberts, Johnson, Joki, Josephson, Roberts, Whiting, Zelinsky, and someone from the ODFW

\section{Presentation -- LA Swamp}

Who: Hood, Jones, Krueger (phone), Thom, Bennett, Collins, Corbett, Doumbia, Ebberts, Johnson, Joki, Zelinsky

Where: PNNL Portland

Presenter: Bill Bennett (EP)

Notes:

- Q: Intent is to have corridors of water movement across Tandy $\mathrm{Ck}$ between the dike breach and the reference site? A: Yes.

- Q: Historic channel was Westport Slough? A: Yes. Q: Connection to Westport Slough is through the Clatskanie R? A: Yes.

- Comment: Good deal to connect to the adjacent reference site; this will aid recovery at the restoration site.

- Q: Need to use all those heavy pilings on the LWD? A: Worried about them floating away.

Comment: Would a more dynamic marsh be better, perhaps? Tandy Ck doesn't push that much water out of the system.

- Q: No connection at the oxbow to the Col R, right? A: Correct, not at this time. 
- Q: Purpose of scrape down is to remove RCG? A: Yes, in some areas. Q: Where will the fill go? A: SW corner of the site. Comment: Ho effect will the scrape down be in removing RCG. There is RCG is the vicinity.

- Q: What kind of emergent veg will be planted? A: Bull rush, sciniplectous, American three-square. Some of the plants to be planted have been found growing in Westport Slough. Q: What about slough sedges? A: Yes, some of this too. Comment: Optimistic about the scrape-down.

- Q: What's the dominant shrub at the ref site? A: Willow, dogwood, rose. Q: Try to mimic the mix? A: Yes. Q: Greatest emphasis on willow? A: Yes, used Borde's species comp proportions.

- Q: Beaver on the ref site? A: Signs of activity but the 10 acres probably couldn't support beaver.

April 18, 2013 -- Project Presentations and Field Trips

Agenda

Presentations

- $\quad$ Steigerwald

- Horsetail

Field trips

- Horsetail

- Steigerwald

Presentation - Steigerwald

Who: Hood, Jones, Thom, Collins, Corbett, Doumbia, Ebberts, Johnson

Where: PNNL Portland

Presenter: Chris Collins (EP)

Notes:

- SC interested in preliminary score. Project has yet to be fully designed.

- Q: Lawton Ck empties into the wetland in the refuge or $\mathrm{u} / \mathrm{s}$ of the dike and into the Col R.? A: Col R.

- Q: Origin of the engineered features? A: Mitigation for construction of Bonneville Dam Second Powerhouse in 1980s.

- Q: Do the T-sheets provide any useful info'? A: Not really.

- Q: In the vision for the restoration, where will the wetland drain, out the new cuts in the natural berm and not through the historical outlet to the west? A: Correct.

- Q: Which months is the river above the $17 \mathrm{ft}$ elev? A: May-June, some of April and July.

- Q: Would the elevated channel be maintained as a foot bridge? A: Part of it (preliminary ideas).

- Comment: Be careful about where the levee breaches are located. Put lots of thought into this.

\section{Presentation - Horsetail}

Who: Hood, Jones, Thom, Collins, Corbett, Doumbia, Ebberts, Johnson

Where: Edgefield, Troutdale, OR

Presenter: Chris Collins (EP) 
Notes:

- $\mathrm{SC}$ interested in final score. The project is ready for construction.

- Comment: Temp data from 2010 are cooler (relatively high flow year) than might be exected on a average flow year; i.e., the restoration to reduce temp's is even more important than indicated by the 2010 data.

- Q: What's the vegetation like? A: Mature ash forest with understory. Q: Will more ash be planted? A: Yes.

- Q: How were the predicted temp's arrived at? A: Weighted average of temp's in Oneata and Horsetail.

- Q: How long is the culvert? A: $\sim 220 \mathrm{ft}$.

- TODO: Send ERTG and Collins the culvert test bed papers.

- Q: How are the new weirs in Culvert\#1 better than the old ones? A: Better fish friendly design meeting NMFS and ODFW criteria.

- Q: Fish passage improvement assessment: does not meeting a given criteria mean there's no fish passage? A: Not necessarily.

- Comment: Root wads do not have to stick in unnatural directions to create habitat.

\section{Field trips to Horsetail and Steigerwald}

Who: Hood, Jones, Thom, Collins, Corbett, Doumbia, Ebberts, Johnson, two folks from USFWS

\section{Next Steps}

- May 2013 ERTG Event -- May 22 TBD. Nothing May 23 because many ERTG members not available. The ERTG will meet May 21, 2013 to score the following projects:

- Sandy R Delta Dam Removal

- North Unit

○ LA Swamp

$\circ$ Horsetail

$\circ \quad$ Steigerwald

- June 2013 ERTG Event - Include participation in the FPL Workshop.

- Finalize Doc \#2013-01 (FPLs) in June 2013.

\section{B.8 ERTG/SC June 18-20, 2013}

\section{June 18, 2013 - Floodplain Lake Workshop}

When: June 18, 2013, 0830-1700 h

Where: Kennedy School, Portland, OR

Who (ERTG members): Bottom, Hood, and Thom

Why: Presentations and discussion on the ecological roles of floodplain lakes in the LCRE, especially as they pertain to juvenile salmon.

Notes: See workshop notes prepared by the Lower Columbia Estuary Partnership 


\section{June 19, 2013 - ERTG+SC Field Visits}

When: June 19, 2013, 0700-1700 h

Where: Columbia River estuary

Who (ERTG members): Bottom, Hood, and Thom

Why: Field visits to the Miller Sands and Trestle Bay projects.

Notes: $\mathrm{n} / \mathrm{a}$

\section{June 20, 2013 - ERTG+SC Discussions and Project Presentations}

When: June 20, 2013, 0900-1200 h

Where: PNNL Portland

Who: Gary Johnson (PNNL), Justin Saydell (CREST), Lynda Charles (Corps), Barbara Cisnersos (Corps), Chris Nygaard (Corps), Blaine Ebberts (Corps), Dave Roberts (BPA), Julie Doumbia (BPA), Phil Trask (PCTA), Ron Thom (PNNL), Greg Hood (Skagit River Coop), Kelley Jorgensen (KJC Consultant), and David Morgan (landowner), plus Dan Bottom (NMFS; by phone).

Agenda:

- Presentation and $\mathrm{Q} / \mathrm{A}$ on Trestle Bay project

- Presentation and Q/A on Miller Sands project

- Presentation and Q/A on Lewis River Tidal WM project

\section{NOTES:}

\section{Trestle Bay Presentation - Matt Van Ess (CREST)}

- USACE project. AAs desire preliminary SBUs. Project in reconnaissance phase.

- Q: Wetted area elevation? A: Used $10.4 \mathrm{ft}$, mean EHW. More conservative than 2 yr flood elev.

- Q: How deep is the bay at low tide? A: Don't have data on the bathymetry.

- Comment: want to understand what kind of fish habitat there might be. This is the first project the ERTG has addressed a bay-type restoration. Need to have knowledge of the bathymetry.

- Comment: Site is already connected so EWRTG will have to assess the "bump", i.e., the added benefit from the breaches

- Comment: Seem to have two principle hypo's 1) get more intertidal area, 2) increase fish densities

- Q: Can ERTG see the fish data from the original breach study? A: Yes, will send it. Definite differences in fish use before and after the original breach.

- Comment: If this proceeds to hydrodynamic modeling would be to examine movements of passive particles. Would provide insight on fish movements (at as passive particles)? Could "seed" the water outside the site, and see how many particles move in. Would be just an indication of water movement. Corps: be aware of the caveat that particles are not fish.

- Comment: It's a kind of levee breach to enhance connectivity. Q: Has this been done in the LCRE before? A: Maybe Gnat 2 is similar. The future Karlson Is project may be similar.

- Comment: $30 \mathrm{~cm} / \mathrm{sec}$ is considered a velocity barrier. But, this is not intended to be a design criterion. Velocity consideration is most important for channel maintenance, not necessarily fish movement. 
- Comment: Interested in how WQ will be improved. Also, don't know but it's possible productivity could be increased. Need to have good water clarity, e.g., for eelgrass growth. Particulate modeling might help.

- Comment: Location in the landscape seems good.

- Comment: Overall want to broaden LHD. Habitats that provide opportunities to broaden the expression of a LH are good. This project could be one of these. Salmon are colonizing fishes. They seem to utilize many different habitats.

- Comment: Concerning eelgrass, did innovative project for BPA to enhance eelgrass recruitment. This site may work. Thom will send GEJ a copy of the report to send out.

- Q: What are some of the risks to the Corps? A: Jetty is still functioning to maintain shoreline and Clatsop Spit. Also, sea level rise is a concern; could use rocks from breaches to develop a breakwater. Can't jeopardize the jetty.

- Comment: Not sure this is analogous to fish use of tidal marshes because don't know a lot about how fish use the estuary/ocean interface in this landscape. Will want to look a size data from Hinton's work in mid-1990s. Surf zone, littoral zone work by Jose has some bearing; some "quiet" area before the fish migrate to the ocean may be imp.

- Comment: Subtidal vs intertidal environments will be a factor in scoring this.

- Q: Any information about avian predators at this site? A: There is a lot from Sand Is across the estuary.

\section{Miller Sands - Matt Van Ess (CREST)}

- USACE project.

- Habitat creation project. ERTG will have to develop an approach to assign SBUs for habitat creation projects (Module subaction 6).

- Sponsor will send GEJ a revised ERTG project template. In addition, Miller Sands report, habitat creation guidelines.

- Q: What area is the area calculation for? A: Everything built above existing grade.

- Q: What do you expect in terms of erosion on the nav' channel side of the supra berm? A: Will do more modeling. Slope of the berm will be a concern.

- Q: The sump"? A: Naturally deep are near Rice Island that's used for hopper dredge disposal. Corps wants to remove material from the sump because it's full. Could use this material at the Miller Sands restoration site. Dredge program could be leveraged for the restoration effort.

- Q: Process to place the material? A: Pipeline dredge to create a button", which is when the elevation is high enough to be out of water, then it's a whole lot easier to build the landform.

- Comment: Will need time for things to stabilize.

- Q: Planting veg on super berm. What about the marsh? A: Yes, will be planting there, too. Comment: Glad to hear this. But, concerned about success to date in previous work to establish native veg communities. Encourage native plant establishment. Planting good, but also control invasive invasions until the native veg can get established.

- Q: Project goal for CRE 1.4? Is it the longer of the two lengths, 0.70 miles super berm or 0.62 miles shrub scrub? A: 0.70 miles. 
- Comment: If you want to demonstrate beneficial use, monitor the site. Especially learn from this as more projects like it come forward.

- Q: Snag Is is not a dredge material placement? A: no, not to our knowledge. It's been relatively stable over last $\sim 75$ yrs.

- Comment: Seems that the project is physically located correctly and the scale is appropriate. High probability it will stay there. Does seem to provide an increase in habitat capacity for juvenile salmon. There will be a flow of material, energy and species within the landscape; good in some respects, but bad for invasions of invasive plant species.

- Comment: Important to preemptively exclude potential invaders by having established native plants. A: Documented presence of some native plant species in the area immediately $\mathrm{u} / \mathrm{s}$ of the existing Miller Sands island.

- Q: Experimental aspects of the project? A: Overall, can we establish the marsh in 20 yrs experimental aspects includes grading aspects, soil augmentation, and planting. Also use of LWD placement to help stabilize the site. Comment: If it costs a lot, don't see much use. Q: How about placement of LWD on channel side of the berm? A: Considering this. Comment: May just happen naturally. Dynamics of wood moving in and off a site helps increase topographic variation. If it doesn't accumulate naturally, then probably not meant to be there.

- Comment: Hope the emphasis doesn't shift from restoring to creation. Generally, creation could mean you might have to expend energy to maintain.

- Comment: There is a trade-off between losing shoal habitat to create marsh habitat. Don't know benefits of shoals for fish. Need to understand the net effect.

- Comment: Need to look at broader context of creation vs restoration. In terms of tradeoffs, place creation in context of what habitats have been lost.

\section{Lewis River Tidal WM Restoration Project - Kelley Jorgensen}

- Purpose: Get preliminary feedback and comments from the ERTG on restoration concepts and issues. No scoring or SBUs.

- Cowlitz Tribe would be the project sponsor. Project is in the early design phase.

- Folks have petitioned to rename Mud Lake to Lake Rosanna after wife of a pioneer landowner.

- Q: Has the self-maintenance of the channels been considered? A: Yes, looking at various river (Col and Lewis) flows. Look at this in terms of design life of the project.

- Q: What do you envision this doing for salmon? A: Creating more off-channel habitat for Col R and Lewis R fish.

- Q: Tide range? A: 2-4 ft.

- Comment: Wonder if juvenile salmon would access Lake Rosanna from the Lewis R.

- Comment: Thinking about the role of the lake. Would be worth it to do some fish sampling in the lake. In general, the vision seems good, but there are uncertainties.

- Comment: Location has benefits. Strategic near main stem Col R. Also useful to Lewis stocks of course. Be a nice Could

- $\quad$ Specific questions for the ERTG: 


\begin{tabular}{ll}
\hline Question/Issue & ERTG Response \\
\hline $\begin{array}{l}\text { Depth of channel excavation (low flow vs. "fish } \\
\text { window" vs. 2-year flood), volume of material and } \\
\text { costs, i.e., What is the optimum elevation to } \\
\text { excavate the channels to benefit fish? }\end{array}$ & $\begin{array}{l}\text { Want to have self-maintaining channels. There'd be } \\
\text { an uncertainty here. }\end{array}$ \\
$\begin{array}{ll}\text { What are some implications or ramifications of } \\
\text { excavating sediment from the lake and outlet } \\
\text { channel? }\end{array}$ & $\begin{array}{l}\text { Makes sense because it wasn't there naturally. } \\
\text { Enhancing outlet channels makes sense bec } \\
\text { enhancing access. Remove sediments down to root }\end{array}$ \\
$\begin{array}{ll}\text { zone of RCG, so hopefully native plants can } \\
\text { recolonize. }\end{array}$ \\
$\begin{array}{ll}\text { Any concerns about temporary impacts to beaver } \\
\text { dams downstream of the lake }\end{array}$ & $\begin{array}{l}\text { For the beaver dams, side cast the wood from the } \\
\text { channel. They'll adjust. }\end{array}$ \\
$\begin{array}{l}\text { What arte CRE 10.X interpretations for mapping } \\
\text { and calculator input purposes? }\end{array}$ & $\begin{array}{l}\text { The culvert removal and placement of a bridge is } \\
\text { probably Subaction 10.1. Channel work is 9.4. }\end{array}$ \\
& $\begin{array}{l}\text { Excavation of sediment in the lake could be a } \\
\text { Subaction } 6 \text { scrap down. }\end{array}$ \\
$\begin{array}{ll}\text { What are some considerations for channel density? } \\
\text { Channel density seems fine }\end{array}$
\end{tabular}

\section{Adjourn}

\section{B.9 ERTG/SC July $17 \& 18,2013$}

\section{July 17, 2013 - Site Visit and ERTG+SC Meeting}

When: July 17, 2013, 1000-1600 h

Where: Julia Butler Hansen National Wildlife Refuge, Cathlamet, WA

Who: Bottom, Hood, Krueger, and Thom(ERTG); Ballentine, Burcham, Ebberts, Gibbons, Helm, Nygaard, Sharp(Corps); Roberts (BPA); Van Ess (CREST); Trask (PCTA); Johnson (PNNL).

Why: 1) Site visit and presentation on the Steamboat project; 2a) ERTG+SC discussions on floodplain lake document and 2b) the Steigerwald project.

\section{Steamboat Site Visit and Presentation - Amy Gibbons (Corps), Chris Nygaard (Corps), and Matt Van Ess (CREST)}

- USACE project. Project in final design phase. Initial construction activities planned for summer 2013.

- Q: How wide will the benches be along the setback levee? A: 26-76 ft wide @ El. $10.5 \mathrm{ft}$.

- Q: What's the plan for the areas you plan to build up? A: Not in a pond and not where there are constrictions.

- Q: Do you see these kinds of terraces in the reference sites? A: No

- Comment: Some wood is good, but shouldn't choke the channel. Use wood densities in reference channels. Caution against going overboard w/ wood. 
- Q: How was the $500 \mathrm{ft}$ breach width established? A: Tried to remove $20 \%$ of the levee w/ the 2 $500-\mathrm{ft}$ breaches.

- Q: How was the width of the channel determined? A: Williams and Assoc design guidelines (2011 for LCRE). Also, Corps checked velocities in a model for the site.

- Q: Landscape context of the project---Winter Slough. How much inundation is allowed? A: Side hinged tide gate; doesn't allow overtopping.

- [ [Should ask Nygaard to review the Salmon Benefits project work on channel density and connectivity. He's done 1st, 2nd, 3rd, etc order channel designations then summarized the results for reference areas.]]

- Q: How much of the Subaction 9.4 (channel) is excavated? A: None. Used remnant channels and and analysis from Crims showing a doubling of channel density over 2006 to 2010. This is the basis for the estimated Subaction 9.4 to be 7.7 acres.

\section{ERTG+SC Session}

Who: Bottom, Ebberts, Hood, Johnson, Krueger, Roberts, Thom, and Trask

\section{FPL Document}

- Workshop was informative. Helped validate some of the uncertainty that the ERTG discovered.

- Predation -- more permanent and deeper probably are more conducive to supporting predators.

- Q: How to make the call whether a water body is an FPL or not? A: ERTG will be making judgment calls. ERTG tries to consider how juvenile salmonids will use the habitat.

- Ambiguity between and FPL and a wetland reflects the reality.

- The large swales are clearly lakes.

- Fish density data at the workshop did not add more to what the ERTG already knew.

- Q: Process $=$ sponsor to determine FPL or not, then the ERTG reviews? A: Yes.

- Criteria for FPL or not = bathymetry, vegetation, etc.

- **Subaction 10.X = weighting factor? Or, is it a $10.2 \mathrm{w} / 0.556$ weighting? Subaction 10.x. Possible solution $=$ Use $10 . X$ series but apply optimum fish density of $0.005 \mathrm{fish} / \mathrm{m} 2$.

- Predation -- front puts it to rest but then predation comes up again in places in the doc.

- Add footnotes for the citations to PPT from the workshop.

- Improve the explanation and clarity of the FPL distinction.

- $\quad$ DECISION = revise the document.

- As work evolves on the 10.X series, and 6.X and (.4, consider updating the "Subaction Clarification" doc.

- $\quad \mathrm{ERTG}=\mathrm{Be}$ good to have a web site for the ERTG materials.

- TODO solicit comments from SC on FPL due 7/19/13.

\section{Steigerwald}

- Fairly high SBUs because of the size. 
- Q: Did the scoring by ERTG assume the improvements the ERTG noted were done? A: ERTG just scored the vision as stated.

July 18, 2013 - ERTG-Only Meeting

Who: Bottom, Hood (phone), Krueger (phone), Thom, and Johnson

Where: PNNL Portland

When: July 18, 2013, 0900-1200 h

Why: Formulate responses to comments from the Steering Committee on the FPL document; provide input for Thom's ERTG presentation at the National Conference on Ecosystem Restoration; and score the backlog.

\section{FPL Document}

- The ERTG discussed the Steering Committee's comments on the FPL document presented at yesterday's meeting at JBH. (If Steering Committee members have additional comments, please send them to me by August 2.) Edits were made to the document and options for weighting the Subaction 10.X series for FPLs were identified. The document will be finalized at the August meeting after Kim Jones returns from vacation and has a chance to review and weigh in on the material.

\section{NCER Presentation}

- The ERTG reviewed and provided feedback on Thom's draft presentation "Ecosystem Restoration in the Lower Columbia River and Estuary: The Role of the Expert Regional Technical Group (ERTG)" to be delivered at the Nat'l Conference on Ecosystem Restoration in Chicago August 1.

\section{Scoring the Backlog}

- The ERTG did not score any projects during the July 18 meeting.

- $\quad$ The ERTG discussed the schedule for August $=8 / 20 / 13$ meeting in Portland $+8 / 21$ as necessary. The ERTG will concentrate on scoring the backlog during the August event, if not sooner.

\section{Adjourn}

\section{B.10 ERTG/SC August 20, 2013}

\section{August 20, 2013-ERTG+SC Meeting}

When: August 20, 2013, 0900-1600 h

Where: PNNL Portland, 620 SW $5^{\text {th }}$ Ave Suite 810

Who: Bottom, Hood, Jones, Krueger, and Thom(ERTG); Ebberts (Corps); Roberts (BPA); Runyon (Cascade Environmental Group); Salakory (Cowlitz Tribe); Trask (PCTA); Johnson (PNNL).

Why: 1) Presentation on the Wallooskee-Youngs project; 2) ERTG+SC discussion on habitat creation; 3) ERTG scoring.

\section{Presentation - Wallooskee-Youngs (John Runyon)}

- Q: Concerns about created vs enhance channels? A: Yes, want to locate and design the created channels using best data and professional; judgment possible. 
- Q: Materials to fill ditches? A: From the excavated channels. Fill barrow ditches with material from levee. [No subaction covers ditch filling.]

- Q: What's going to happen to the BPA road used to access the transmission towers? A: Building a new submerged road. Also adding two $100 \mathrm{ft}$ X $100 \mathrm{ft}$ tower pads. The right-of-way is not in the new channel network. Q: Explain the submerged road? A: Like those at boat landings; just drape over the surface.

- Q: Does grubbing drop elevation enough to eliminate invasives? A: Probably not, but everything helps.

- Q: Examples of tower footings that get submerged? A: Sandy River delta has some.

- Q: Plans for public kiosk? A: Nat'l Parks Historical Service may help.

- Q: Salinity range at the site? A: See p.8 of template. 0-9 ppt. Know from marsh plants that invasives are not likely to be a problem.

- Q: What's the mean elev of marsh sfc? 5.5-6.0 NAVD88.

- Q: How much have things changed from the original template? A: Channel network about same. Treatment on levee itself is much more extensive.

\section{Habitat Creation (ERTG+SC)}

- Corps has two projects underway: Miller Sands and Wallace Island Complex. Working to develop a study report for each that gives good idea of a design concept, but before have to engage costshare.

- Wallace pertains to some shoaling areas near Wallace Is.

- ERTG to review the Corps' design doc's.

- Chris Nygaard is Corps' technical guy on habitat creation.

- May do a field trip to see some created habitats.

- Many of the LCREP reference sites were actually habitat creations way back when.

- Useful for ERTG to have a sense of the universe of different types of habitat creation work.

- Habitat creation can involve adding materials to build up and scraping down to a preferred elevation. Two module actions pertain to habitat creation:

\begin{tabular}{|c|l|c|c|c|}
\hline Subaction & Description & $\begin{array}{c}\text { Total Module Goal } \\
\text { (acres) }\end{array}$ & $\begin{array}{c}\text { Ocean Total } \\
\text { SBUs }\end{array}$ & $\begin{array}{c}\text { Stream Total } \\
\text { SBUs }\end{array}$ \\
\hline 6.2 & Beneficial use demo' & 100 & 0.3 & 0.2 \\
\hline 6.3 & $\begin{array}{l}\text { Beneficial use dredge } \\
\text { material }\end{array}$ & 500 & 1.5 & 0.75 \\
\hline
\end{tabular}

- TODO Phil and Gary to review the module elements for subaction 6. 
- There are fish data from the habitat creation sites. See work on historical breaches work by Diefenderfer et al. (2009) ${ }^{1}$.

- Also, will need to examine $\mathrm{u} / \mathrm{s}$ and $\mathrm{d} / \mathrm{s}$ effects from habitat creation.

- Will need to consider the source of the dredge material.

- Methods: 1) pump and deposit nearby, 2) hopper dredge collection and deposit away, 3) remove material from sumps and use it to create habitat.

- Most cost-effective way is to use material from Corps' routine maintenance dredging. Need to reflect -- is this simply part of the existing, highly managed system.

\section{Scoring (ERTG-Only + notes from conference call on Kandoll 2)}

- Added Jones' scores to complete scoring for Trestle Bay.

- Scored Wallooskee-Youngs, Steamboat Slough, and NU Ph 2 Widgeon/Deep.

- Worked on Kandoll 2 scoring, but had questions for the sponsor. (A conference call was held on August 21, 2013.) Notes follow:

○ Call to Ian Sinks, CLT, 8/21/13. Krueger, Jones, Hood, Johnson, Thom, Roberts, Sinks.

- After discussions with BPA and the sponsor, ERTG decided to treat the actions as a stand alone project (Kandoll 1 constructed in $2005+$ Kandoll 2 constructed in 2013). Note: the sponsor needs to correct the 10.1 acreage in the latest version of the template.

- Q: Explain more about constructing beaver huts. A: Following work by Hood, building "check dams." Q: Has this been used elsewhere? A: Probably, but CLT hasn't done it before.

Q: What's the red "XX" deal in the diagram? A: It's a flow resister; trying to make sure flow moves in and out of the site via the breach in the Grays, not Seal Slough. Q: Is it possible to remove the resister structure if it turns out to be a problem? Same w/ beaver starter structures? A: Beaver deals aren't anticipated to be a problem. On the other hand, the resister structure is necessary to reduce risk for land owners downstream. Without the structure, they'd have to close the Kandoll 1 culverts.

- Q: Explain difference between beaver dams and starter dams? A: Starter dams are 6-7 smaller posts placed vertically in channel so give beaver a place to start, whereas the dam is same except with a 12-14 inch diameter log placed horizontally.

Q: Explain the habitat mound diversions? A: Connect channel network to barrow ditch along Kandoll road to divert flow from going into Seal Slough via the culvert.

$\circ$ Q: Road will be maintained? A: Yes, paved to the culverts now.

- After the call, the ERTG scored Kandoll 2.

\section{Adjourn}

\footnotetext{
${ }^{1}$ Diefenderfer HL, AB Borde, GC Roegner, EM Dawley, MT Russell, and AS Cameron. 2010. "Ecological Trajectories and Salmon Habitat Functions of Historical Dike Breaches and Created Islands in the Columbia River Floodplain, USA." Appendix C in: Evaluating Cumulative Ecosystem Response to Restoration Projects in the Lower Columbia River and Estuary, 2009, GE Johnson and HL Diefenderfer (eds.). PNNL-19440, prepared for the U.S. Army Corps of Engineers, Portland District, Portland, Oregon, by Pacific Northwest National Laboratory, Richland, Washington.
} 
B.33 



\section{Distribution}

No. of PDF

Copies

Catherine Corbett

Lower Columbia Estuary Partnership

811 SW Naito Parkway, Suite 120

Portland, Oregon 97204

Julie Doumbia

Bonneville Power Administration

PO Box 3621

Portland, Oregon 97208

Blaine Ebberts

U.S. Army Corps of Engineers

333 SW First Avenue

Portland, Oregon 97204

Jim Geiselman

Bonneville Power Administration

PO Box 3621

Portland, Oregon 97208

Lynne Krasnow

NOAA Fisheries

1201 NE Lloyd Blvd.

Portland, Oregon 97232
No. of PDF

Copies

Russell Scranton

Bonneville Power Administration

PO Box 3621

Portland, Oregon 97208

Cindy Studebaker

U.S. Army Corps of Engineers

333 SW First Avenue

Portland, Oregon 97204

Ben Zelinsky

Bonneville Power Administration

PO Box 3621

Portland, Oregon 97208

\section{Local Distribution}

Pacific Northwest National Laboratory

Gary Johnson

Nichole Sather

BPO

SEQUIM 


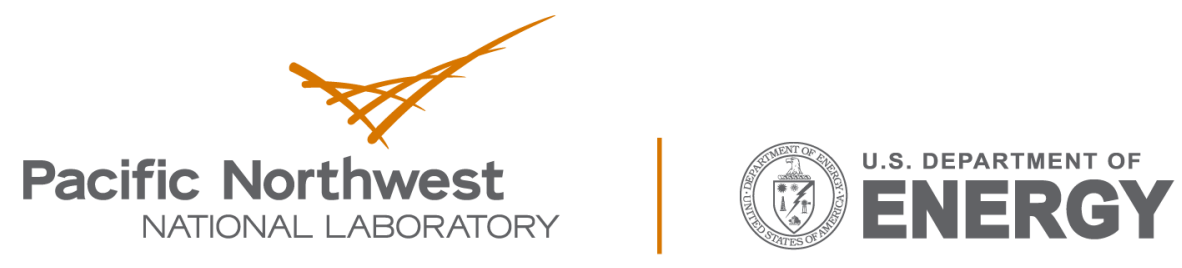

Proudly Operated by Battelle Since 1965

902 Battelle Boulevard

P.O. Box 999

Richland, WA 99352

1-888-375-PNNL (7665)

www.pnnl.gov 